Pecvnia, núm. 24, 2021, pp. 33-66

\title{
El afán por preservar y proteger. La custodia del dinero en efectivo en el XVIII burgalés The desire to preserve and protect. The custody of cash in the XVIII century in Burgos
}

\author{
Francisco José Sanz de la Higuera \\ I.E.S. "Torreblanca" Sevilla \\ C/ Torregrosa, 85, 41016-Sevilla (España). sanzdelahiguera@gmail.com
}

\section{Resumen}

La inexistencia de entidades bancarias en las que depositar los caudales particulares hacía preciso, en el Antiguo Régimen, y más, en concreto, en el siglo XVIII, solucionar tal problemática de la mejor manera posible. El burgalés del Setecientos se las ingeniaba para proteger el dinero en efectivo atesorado merced a su ocultación en el interior del mobiliario contenedor disponible en el interior de las viviendas. En los inventarios de bienes más exquisitos nos adentramos, además, en las estancias en las que se encontraban ubicados dichos muebles. Sus "secretos" eran, en la práctica, cajas de caudales habilitadas en las entrañas del mobiliario contenedor. En el Burgos del Setecientos aparece dinero en efectivo en el $49.2 \%$ de los inventarios recopilados. En el $27.2 \%$ de ellos disponemos del lugar en que era protegido de miradas indeseables.

Palabras clave: Dinero; Mueble contenedor; Burgos; Siglo XVIII.

\section{Abstract}

The inexistence of banking entities to deposit the particular flows made necessary, in the Old Regime, and more specifically, in the Eighteenth century, to find a suitable solution. In this period, the Burgos civilians managed to protect the treasured cash by hiding it inside secret containers in the furniture of the houses. In the most exquisite inventories of goods, the rooms where this furniture were located are also shown. Their "secrets" were, in practice, cash boxes enabled in the bowels of the container furniture. In the Burgos of the Eighteenth Century, cash appears in $49.2 \%$ of the inventories collected. In $27.2 \%$ of them, the place where it was protected from undesirable looks is exposed.

Keywords: Money; Container furniture; Burgos; Eighteenth Century. 


\begin{abstract}
"... no tenían notizia ubiese dejado la suso dha más Vienes ni papeles que los Inventariados y que solo se habian encontrado en un arcón grande Veinte y dos Rs como perdidos y derramados entre la rropa en diferentes monedas de plata, Vellón y Calderilla y otros Doze Rs deel Desempeño de un guardapies" 1 .
\end{abstract}

\title{
1. Introducción, fuentes documentales y aproximación bibliográfica
}

En 455 de los 925 inventarios de bienes recopilados para el Burgos del Setecientos, es decir, en el $49.2 \%$ de los hogares a que hemos tenido acceso documental, el escribano que evaluó sus pertenencias constató la existencia de dinero en efectivo. La carencia de información para el otro $50.8 \%$ de los hogares implicados en esta reconstrucción nos ha de hacer conscientes de que las aseveraciones y tesis que se pergeñan estarán siempre lastradas por tales vacíos documentales. En efecto, y lamentablemente, el escribano no se aproximó en todos ellos, de una manera

34 exhaustiva, al "lugar" en que dichos caudales se guardaban, ya sea en lo tocante al mueble en que se encontraban depositados 0 , por otra parte, a la estancia en que ambos, dinero y mueble, se hallaba ubicados. Tampoco fue, a veces, excesivamente exigente en la constatación de qué monedas había en cada caso. En el inventario post-mortem de, por ejemplo, el maestro tejedor de lienzos José Martínez, se significó que "Primeramente se reconoció una Arca que se halla en un quarto entrando en la Sala pral a mano derecha, y en la que manifestó (...) custodiaba su difunto marido los dineros, y se halló existir los que se siguen..." 2 . El tenor de este apunte no es lo habitual. No interesa en estas páginas analizar las cantidades de dinero atesorado en los interiores domésticos en sí mismo ${ }^{3}$ cuanto efectuar una indagación crítica sobre cómo resolvían los burgaleses del XVIII la problemática de proteger sus alcancías del hurto 4 . Siempre desde la presunción de que la totalidad de los implicados tenían constancia de "...No haber Ocultado Vienes algunos por si ni otra persona, como tampoco tenerlos en Otra ninguna parte" ${ }^{\prime 5}$. A la postre, se va a realizar un seguimiento del "... físico dinero al tiempo que murió" ${ }^{6}$, poniendo énfasis en las temáticas señaladas de cuánto, dónde y de qué manera se protegían los caudales, de la forma en que en el post-mortem de Ángela Dueñas se certifica "...no tenían notizia Ubiese dejado la suso dha más Vienes ni papeles que los Inventariados, y que sólo se habían encontrado en un arcón grande Veintte y dos

\footnotetext{
1 Archivo Histórico Provincial de Burgos. Protocolos Notariales -en lo sucesivo AHPB. PN-. Juan Antonio Fernández Guilarte. Legajo 6993 (5 de agosto de 1723), folio 314.

2 AHPB. PN. Antonio Rafael Pérez. Legajo 7269/2 (30 de abril de 1779), folio 4.

3 Sanz de la Higuera (2013: 13-40).

${ }^{4}$ Véanse, en otras propuestas de análisis, Alloza Aparicio (2000: 143-185), Ortego Gil (2010: 449470) y Sánchez-Arcilla Bernal (2001: 43-109).

5 AHPB. PN. Gregorio Padrones. Legajo 7196 (16 de diciembre de 1765), folio 554.

${ }^{6}$ AHPB. PN. Gaspar Tomé González. Legajo 8309 (27 de enero de 1753), folio 243.
} 
Rs como perdidos y derramados entre la rropa en diferentes monedas de plata, Vellón y calderilla y otros Doze Rs deel Desempeño de un guardapies"7.

En el tratamiento de las circunstancias sugeridas, se suscitan varios aspectos que enturbian el modelado del análisis propuesto. Una de las deficiencias más hirientes deviene de la existencia de inventarios de bienes en los que el escribano-notario dejó constancia, irrefutable, de la disponibilidad de dinero en efectivo entren los pertrechos del hogar, pero nos hurtó la consideración de en dónde se hallaba guardado -tanto el mueble como la estancia o el tipo de moneda-. Ese es el caso de lo verificado en casa del maestro sillero Vicente Rodrigo. Se computaron 23.000 reales de vellón ${ }^{8}$ "que en dinero efectibo declaró el zitado (...) tener en su poder, que exibió y contaron los zitados tasadores a presencia de los referidos". Empero, se pasó por alto en qué mueble y en qué estancia estaban depositados ${ }^{9}$. Es usual indicar, por parte del escribano, la existencia de "Dinero que parezió en ser" o "Dinero effectivo" sin más descripción ${ }^{10}$, pero sin concretar, en efecto, su localización. Modélica, aunque imperfecta, es la anotación del escribano en el hogar del notario apostólico y procurador del número del Real Adelantamiento José Santos del Río y Nalda, poseedor de 2.000 reales "que parecieron en casa (...) que se fueron contando en moneda de oro, plata, Calderilla y ochavos"11. Un fenómeno semejante ocurre con María Fernández Mata. Se anota la presencia de 182 reales de vellón, dinero "que parezio aver en un talego", sin concretar en qué lugar. Quizá fuera en uno o en los dos escritorios de concha de su vivienda ${ }^{12}$.

El procedimiento de inspección para el quehacer del inventario supuso -como, por ejemplo, se relata en el documento del capellán del número en la Catedral José Ruiz-, que "...abrieron un escriptorio Salamanquino y las Navetas de un bufete de nogal en donde sólo se hallaron 925 Rs con barios papeles (...) los que volbieron a Cerrar y recojieron las llaves de dho escriptorio y Nabetas, como también las de los Baúles y Cofres que en dha Casa se hallaron"13. Lo habitual era que los caudales estuvieran en las inmediaciones del lecho nocturno del agonizante. Para el canónigo

AHPB. PN. Juan Antonio Fernández Guilarte. Legajo 6993 (5 de agosto de 1723), folio 314.

8 El dinero en efectivo se indica siempre, salvo excepciones, en reales de vellón, si bien su aparición en los inventarios de bienes suele ser habitualmente expresada en oro, plata y vellón, según el caso.

9 AHPB. PN. Jacinto Álvarez. Legajo 7114 (13 de marzo de 1754), folio 32.

10 Véanse, por ejemplo, el labrador José Díez en AHPB. PN. Martín Robredo. Legajo 6970 (26 de mayo de 1730), folio 216; el maestro pintor Fulgencio Martínez en AHPB. PN. Vicente Mariscal. Legajo 7292 (26 de febrero de 1797), folio 28; el comerciante Pedro Domínguez de la Torre en AHPB. PN. Miguel Palma Valderrama. Legajo 7287 (6 de agosto de 1791), folio 101; el escribano Pedro Álvarez en AHPB. PN. Manuel Peña. Legajo 7111 (8 de enero de 1759), folio 251; el panadero Francisco Asenjo en AHPB. PN. Bernardo Alonso Illera. Legajo 7184 (15 de enero de 1763), folio 14 o el aristócrata Francisco Melgosa y Lerma en AHPB. PN. Santiago Romo. Legajo 6983 (17 de agosto de 1744), folio 540.

11 AHPB. PN. Domingo Ibáñez Varona. Legajo 6921 (17 de marzo de 1700), folio 4.

12 AHPB. PN. Juan Francisco Gandía. Legajo 6877 (10 de diciembre de 1705), folio 805.

13 AHPB. PN. Ángel Arnaiz. Legajo 7173 (7 de abril de 1777), folio 466. 
en el Cabildo Catedral Santiago Díez Guerra "habrieron un Arcón que está detrás de la Cama en que murió dho difunto y en él Parecieron diferentes Monedas de oro y Plata"14. El más aparatoso fue el contexto que rodeó el óbito del arzobispo Perea ${ }^{15}$. El Ordinario era poseedor de una inmensa suma de dinero en efectivo que, con sumo secreto y cuidado, se hallaba en "Un Arcón que estaba en dha pieza o retrete interior inmediato a el cuarto donde falleció Su Illma, cuyas llaves estaban en una papelera que se hallaba en el estante de los libros (...) llaves pequeñas que sacó de entre los libros". En una faltriquera, varios bolsillos de seda y talegos de estopa se ocultaba un auténtico tesoro ${ }^{16}$. Ramón Larrínaga y Arteaga, abad de San Quirce y dignidad y canónigo de la Catedral, disponía de 588 reales, que "se encontraron en [un] Caxón, ubicado en el "Quarto Retiro tras del oratorio"17. Del mismo tenor es lo que ocurría en casa del aristócrata Francisco Melgosa, quien ocultaba su dinero "En dos papeleras que estaban en la Alcoba deel difunto en múltiples monedas ${ }^{18}$. Más modesta, a la hilandera $M^{a}$ Teresa García se le computaron 576 reales de vellón. Un cirujano y otros vecinos "la havian Visto muertta en la Cama". Posteriormente, "otros dos vecinos y dos mujeres, las que la Sacaron de la Cama en que estava, y Registrándola (...) y andando buscando por dha Cama" se toparon con un "Volsico". Y dentro de él "se encontró a la cabecera Uno de Pellejo blanco y en él dos bolsittas, la una de Pellejo y la otra de trapo Como el de Lienzo, y en ellas se 36 encontraron, En presencia de todos, Un Doblón en oro, ottro Doblón de a cinco pesos, tres Doblillas de a veintte rrs y Siette Pesos fuertes, Corttados, con un quartto en Calderilla"19.

También bastante recóndito era el procedimiento ideado por el mercader de paños y sedas Francisco Sainz de Viniegra. Había diversificado la ocultación de su dinero en dos escenarios. En primera instancia, el grueso de sus caudales, unos 48.393 reales de vellón, se encontraron "En un Escriptorio Salamanquino que se alla en un quarttitto de tras de la Alcoba de el Quarto pral, donde murió (...), cuia llave se allava recojida". En segundo término, 2.985 reales fue el dinero que, en diferentes talegos, "se alló en la tienda"20. El también mercader Francisco González Carrera llevó a cabo una similar estrategia. 7.830 reales y 20 maravedíes "parecieron en el Quarto titulado de la librería, detrás de la Efigie de un Ssmo Cristo (...) con sus premios, metidos en un Taleguito pequeño de Lienzo" y 1.204 reales y 24 maravedíes "así bien parecieron en esta Especie en una de las Navetas de un

\footnotetext{
14 AHPB. PN. Alonso García Manrique. Legajo 6811 (25 de octubre de 1713), folio 377.

15 Sobre este clérigo véanse Sanz de la Higuera (2006: 149-178) y, en general, Barrio Gozalo (2000).

${ }^{16}$ AHPB. PN. Santiago Romo. Legajo 6983 (23 de febrero de 1744), folios 177-178.

17 AHPB. PN. Jacinto Álvarez. Legajo 7268 (16 de diciembre de 1773), folio 33.

18 AHPB. PN. Santiago Romo. Legajo 6983 (17 de agosto de 1744), folios 537-540.

19 AHPB. PN. Gregorio Padrones. Legajo 7140 (17 de octubre de 1764), folio 100.

20 AHPB. PN. Francisco Villafranca. Legajo 7098/1 (16 de diciembre de 1768), folios 17-18. Véanse también los apuntes sobre el mercader de paños Tomás Martínez Velasco en AHPB. PN. Bernardo Alonso Illera. Legajo 7194/6 (23 de junio de 1788), folio 2.
} 
Escritorito enbutido en Concha y Gueso", sito en el "Quarto al Jardín"21. Los comerciantes eran profesionales de costumbres arraigadas, como demuestra el inventario de Pedro Bernáldez de Velasco22. De sus caudales, depositados en "Ocho talegos de hechar dinero" y "Quatro Bolsas para moneda", se dice que "Aviéndose havierto un escriptorio, en donde dho Difunto Regularmente ponía el dinero, parecieron las Cantidades siguientes..."23.

El dinero en efectivo era, en las categorías socio-profesionales más modestas, bastante escaso. Empero, estaba bien protegido de miradas ajenas, como desmuestra el maestro de obras ${ }^{24}$ Francisco Bastigueta, poseedor de 225 reales y 30 maravedíes, que "dixeron haver encontrado en la Gaveta de una Mesa que está en el Quarto en que havitaba y dormía"25. Más difuso fue lo significado en el de José Hidalgo, mesonero, calesero y labrador (28), de quien se señala que "haviendo reconozido mui por menor los cofres, Arcas, navettas y demás que se tubo por conveniente para efecto de ver si se encontravan algunas Otras alajas que las Ynventariadas, Dineros o papeles (...) sólo se encontró..." 2.600 reales. Lamentablemente, no se detalla su localización ${ }^{26}$.

Las cantidades localizadas era, en ocasiones, tan substanciosas, y el personaje de tanta altura socio-económica y política, que el dinero en efectivo fue traído y llevado de aquí para allá, en su ansia por evitar hurtos. El inventario de bienes de Cayetano de Arriaga, alcalde mayor perpetuo e Intendente de la Palencia, es excepcional. El dinero, en principio, fue localizado en una mesa de nogal del "cuarto pral que cae al Patio", donde "se hallaron en un talego" 138.256 reales de vellón, que fue la cantidad a la que "Asciende el Dinero en especie que se a encontrado". Después "se puso y metió en un Baúl el Dinero y [la] platta labrada", todo lo cual se trasladó a "un Cajón del Oratorio", para, finalmente "y con las mismas" se llevado y colocado "dho Vaúl en el Archivo de (...) la Ciudad, cuia llave recojió el dho Señor intendente"27. Más sencilla resultó la inspección en casa del maestro sillero y alquilador de mulas Jacinto Pérez, donde se "reconocieron los Cofres y arcas para Ver lo que tenía en ellos y allaron diferentes monedas"28.

Se ha rastreado alguna situación confusa, y paradójica, como la que nos depara el inventario post-mortem de la tendera Rosa Tornadijo. Se indica la existencia de 56.045 reales de vellón, localizados en un "Arcón grande de pino, que se halla en el Quarto de dha Casa" y se enfatiza que "aunque se reconozieron otras Arcas y

21 AHPB. Justicia Municipal (JM en lo sucesivo). Alonso Melo Peña. Legajo 987 (16 de noviembre de 1778), folio 12.

22 Sanz de la Higuera (2017a: 361-384).

23 AHPB. PN. Domingo Ibáñez Varona. Legajo 6935 (17 de noviembre de 1723), folio 780.

${ }^{24}$ Sanz de la Higuera (2018a).

25 AHPB. PN. Juan Antonio Fernández Guilarte. Legajo 7022 (28 de agosto de 1757), folio 539.

${ }_{26}$ AHPB. PN. Gregorio Padrones. Legajo 7136 (27 de abril de 1764), folio 158.

27 Archivo de la Depilación Provincial de Burgos. Fondo Berberana -en adelante ADPB. FB-. José Arcocha. Legajo 107 (9 de julio de 1779), sin foliar.

28 AHPB. PN. Martín Robredo. Legajo 6969 (2 de septiembre de 1729), folio 378. 
Baúles no parecieron más". No obstante, después se indica que, en la segunda tienda, se toparon con 2.792 reales que "contenía una calzeta vieja que (...) manifestó haver hallado en la mañana entre unas tenajas" (sic). Ítem más, 4.000 reales "declaró haver hallado en una olla"29. Una similar falta de concreción depara el inventario del capellán en el Hospital de Barrantes Juan Pérez Ceballos, propietario de "Una bolsa de Seda con 200 Rs de plata" y 9.115 reales "hallados en los Quartos de su habitación en el Hospital"30. Afortunadamente, nos topamos con inventarios en que el detalle llega a lo pormenorizado. Así, por ejemplo, en el del beneficiado en San Lorenzo y Capellán del número en la Catedral José del Cerro se señala que había 1.998 reales de vellón "en las navetas del escriptorio y otras partes donde se discurría podía averlo". Dicho escritorio estaba ubicado en el "Primero Quarto" de su vivienda ${ }^{31}$. En el inventario del maestro tajador de carnes ${ }^{32}$ Manuel Chabarría se localizaron 1.646 reales, cantidad "que parezió en un escriptorio pequeño (...) y aunque se rreconozieron diferentes arcas, Cofres y ottros arcones no parezió más que lo expresado"33. El inventario del mayordomo del Cabildo Catedral Bernardo Helguero pone el contrapunto al anterior. En su caso, "se reconoció mui por menor el escritorio, cuia llave se avia recojido y en el se encontraron" en un talego 21.121 reales, en otro 15.585 reales y 30 maravedíes, en otro 1.020 real, en otro 4.910 "y últimamente en otro talego se contaron" 1.420 reales. "Por manera que las dhas 38 Partidas y monedas que se allaron en dho escriptorio ascienden a" 53.056 reales y 30 maravedíes. Y "preguntado si tenían noticia de que en alguna otra parte hubiese más porción, respondieron que siempre vieron husar a dho dn Bernardo deel citado escriptorio para recoger y metter su Caudal en dinero, y espresando (...) uno de los dhos hijos que también alguna vez lo recojía en una papelera que se alla en el Quarto principal donde murió, se tomó la lleve que era una de las que se allan en dho escriptorio y abrió a presencia de la citada papelera en donde no se alló dinero alguno"34.

En general, la mayoría de los inventarios post-mortem recopilados indican cuáles eran las circunstancias con las cuales se protegía el dinero en efectivo. Del capellán del número de la Catedral José Jiménez Luna se dice que "se hallaron (...) en dho escriptorio Mill Quinientos Rs en un talego de Estopilla en pesos fuertes, los que se

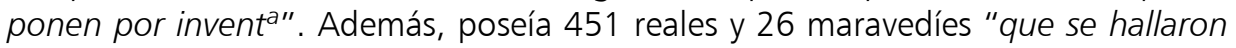
en dho escriptorio en un doblón de a ocho y dos sencillos en un bolsillo pequeño de seda echura de rred"35. El beneficiado en la parroquia de San Lesmes Lesmes Bravo Pascual atesoraba 1.653 reales de vellón "que parecieron en diferentes monedas de oro y plata en las Navetas del escriptorio o bufete que existía en el

\footnotetext{
${ }^{29}$ AHPB. PB. Vicente Mariscal. Legajo 7291/6 (15 de marzo de 1794), folio 9.

30 Archivo Capitular de la Catedral de Burgos (ACCB). Manuel Ruiz Cotorro Libro 133 (10 de enero de 1776), folio 552.

31 ACCB. Juan Antonio Fernández Guilarte. Libro 98 (3 de enero de 1735), folio 702.

32 Sanz de la Higuera (2019).

33 AHPB. PN. Juan Antonio Fernández Guilarte. Legajo 7003 (17 de junio de 1733), folio 389.

${ }^{34}$ AHPB. PN. Nicolás Martínez Vivanco. Legajo 7147 (2 de febrero de 1763), folio 465.

35 AHPB. PN. Agustín Busto. Legajo 7066/2 (9 de mayo de 1763), folio 369.
} 
Quarto del Dormitorio" 36 . En los interiores domésticos de la vivienda ocupada por el beneficiado en Santa Águeda José Pereda Arce "abrieron y reconocieron (...) los caxones y Navettas de la Papelera, esttantte de Libros y mesas que van ymventtariadas y encontraron y allaron en ellas tres mill quinientos y ochentta y tres rs y siette mrs efecttivos en diferentes monedas Usuales y corrientes" ${ }^{37}$. Para Casilda Gallo y con Miguel de la Moneda, regidor perpetuo y rentista, nos topamos, en el interior del "Quarto del gabinete de papeles", donde "se encontró en uno de los cajones de [una] papelera diferentes papeles, se quedaron para reconocer a su tiempo, y así mismo una Volsitta y dentro de ella 1.100 Rs en pesetas", así como 178 reales, que "parecieron en las faltriqueras de uno de los Calzones de dho don Miguel"38. Francisco de la Infanta, "hacendado", ex tendero y empresario lanero, depositaba su dinero en un arcón o archivo de nogal, ubicado probablemente en el "Quarto altto". En su interior donde se hallaban depositados en "Treze talegos de echar dinero" -tasados en 12 reales- 24.234 1/2 reales ${ }^{39}$.

La minuciosidad era extrema en muchas ocasiones. En el inventario, por ejemplo, del tendero Juan Martínez Céspedes se hizo "rejistro de dos Baules que se hallan en el Entresuelo de la nominada Casa y de ottros Arcones que hai en ella y sólo en uno de los Citados Baúles se halló un Bolsillo, el Qual sacó" y contó40. Unas peripecias similares ocurrieron en casa de la tendera Rosa Tornadijo. Se anotaron 56.045 reales extraídos de un arcón grande de pino, "y aunque se rreconocieron otras Arcas y Baúles no parecieron más"41. Al escribano Juan Francisco García de la Penilla se le anotaron 1.846 1 1 reales, que "se encontraron en un escriptorio Salamanquino" -sito en los "Quartos alttos"- en varias monedas, más 600 reales que fueron localizados "en una navetta Secreta del dho Escriptorio"42. En el inventario del también escribano Juan Antonio Herrera Tomé el recorrido, igualmente exhaustivo, generó las siguientes ocurrencias. En primera instancia, en "uno de los Cuartos de su habitación (...) [en] un Arca de pino pequeña se encontraron en unos Secretos que incluía" 2.528 reales y 25 maravedíes. En segundo término, "Después de lo qual, bajado al Portal de la Citada Casa, pareció vajo de una Peña de un poyo que ay en él un Votte de hojadelata y en él (...) monedas", "que son las únicas -enfatizó el escribano- que parecieron en dha Casa"43. Descuella, en última instancia, el inventario post-mortem del Notario mayor del Tribunal eclesiástico Francisco Antonio Munar. El dinero en efectivo apareció, por una parte, en un cofre, dispuesto con dos cerraduras y una lleve, "dentro deel qual se alló" un conjunto de talegos y bolsos, preñados de monedas" y además, en segundo término, se

\footnotetext{
${ }^{36}$ AHPB. JM. Bernardo Alonso Illera. Legajo 983 (19 de junio de 1781), folio 13.

${ }^{37}$ AHPB. PN. Jacinto Álvarez. Legajo 7119/2 (16 de enero de 1766), folio 34.

38 AHPB. PN. Santiago Romo. Legajo 6983 (21 de octubre de 1744), folio 135.

39 AHPB. PN. Fermín Villafranca. Legajo 7273 (21 de abril de 1797), folios 826 y 866.

40 AHPB. PN. Gregorio Padrones. Legajo 7140 (15 de febrero de 1790), folio 335.

41 AHPB. PN. Vicente Mariscal. Legajo 7291/6 (15 de marzo de 1794), folio 9.

42 AHPB. PN. Domingo Ibáñez Varona. Legajo 6942/2 (27 de febrero de 1737), folio 79.

${ }^{43}$ AHPB. PN. Gregorio Padrones. Legajo 7138 (29 de septiembre de 1779), folio 673.
} 
anotaron 13 doblones (810 reales de vellón) "que pareçieron en los Calzones que solía traer puestos" 44 .

Aunque ocurre en muy pocas ocasiones -han sido recopilados solamente 19 apuntes, es decir, únicamente en el $2 \%$ de los inventarios recopilados-, entiendo que la inmensa mayoría de los muebles contenedores en que se documenta la existencia de dinero en efectivo estaban dotados de uno o varios "Secretos" (sic). El escritorio, y otros muebles contendedores, disponía de una parte central, "que a su vez escondía cajones interiores (...) escondrijos" de muy difícil acceso ${ }^{45}$. Lamentablemente, los escribanos no hicieron mención habitualmente de tal circunstancia, con excepción de un exquisito número de anotaciones. El 52.6\% de ellos se hayan asociados a los escritorios (10 ocasiones), el $26.3 \%$ a las papeleras ( 5 ocasiones), el $10.5 \%$ a los arcones (2 ocasiones) y sendos $5.3 \%$ a un baúl y a un arca. Todos ellos, potencialmente, estaban diseñados para salvaguardar dinero, merced a la ocultación más sibilina. Por lo que respecta a los escritorios, el $40 \%$ de dichos muebles con "Secreto" se dan en casas de burócratas. En el post-mortem del escribano Juan Francisco García de la Penilla "se encontraron [1.646 1/2 reales] en un escriptorio salamanquino" y otros 600 "en una naveta Secreta del dho Escriptorio"46. En el inventario del también escribano Francisco Fernández Cotarello 40 se tasó un escritorio de nogal con 8 navetas y "Dos Secretillos" 47 . El Notario mayor de la Audiencia Arzobispal Antonio Solares era propietario de dos escritorios de nogal, hechura de Salamanca, dotados, cada uno, con "Su Secreto" (52). El procurador del número Francisco Onzaviña protegía su dinero "en uno de los Escriptorios" en "una nabetilla Secreta"48. El 10\% de dichos escritorios con secreto aparece en las viviendas de los profesionales de los servicios públicos. El tabernero Diego Arroyo disponía, entre sus enseres, de "Un Escriptorio de quatro altos con su puerta en medio, embutido de ébano y gueso y chapa de concha en el medio, y por extremo un bronze a la entrada de la Zerradura, en él dentro a las puertas sus tiradores de Nogal, embutidos de Nogal con perfiles de Chopo, y la gabeta interior Pareciendo ser Una son dos y a la parte de atrás Su Secreto" en el que guardaba 90 $1 / 2$ reales "de todo Jenero de monedas" 49 . Una parte importante de dichos secretos, el 30\%, se asocia al mobiliario de los nobles rentistas. Antonio Fernández de la Mata, noble rentista, era poseedor de "Un Escrittorio [grande] de taracea con su Secreto" ${ }^{10}$. El también noble rentista Agustín Peñas Mendoza disfrutaba de dos escritorios de ébano, dotados con 8 navetas, los cuales "en el friso de la cornisa [tenían] su Secreto y en el pedestal lo mismo"51. El marqués de Villacampo, Antonio Fernández de Castro Lilla, atesoraba "Un Escriptorio embutido de barias maderas

\footnotetext{
44 AHPB. PN. José Fernández Guilarte. Legajo 6892 (1 de junio de 1701), folio 323.

45 Piera Miquel (2012: 165).

46 AHPB. PN. Domingo Ibáñez Varona. Legajo 6942/2 (27 de febrero de 1779), folio 79.

47 AHPB. PN. Martín Robredo. Legajo 6958 (5 de julio de 1709), folio 294.

48 AHPB. PN. Martín Robredo. Legajo 6958 (5 de septiembre de 1709), folio 345.

49 AHPB. PN. Matías Calleja. Legajo 6956/2 (28 de abril de 1706), folio 24.

50 AHPB. PN. Alonso García Manrique. Legajo 6817 (11 de marzo de 1719), folio 78.

51 AHPB. PN. Juan Antonio Fernández Guilarte. Legajo 7005 (23 de octubre de 1736, folio 591.
} 
de payses, de Perspectiva, estampado, con diferentes Secretos", ubicado en el "Salón prinzipal"52. Otro 20\% ocurre en casas de clérigos. El beneficiado en San Lorenzo José Velasco gozaba de un escritorio salamanquino de nogal con "Secreto"53. El canónigo catedralicio Diego Fernández Cormenzana usufructuaba un escritorio antiguo, dotado de una "papelera a forma de Secreto" 54.

Las papeleras con secreto implican a dos clérigos (suponen el $40 \%$ de este mueble) y a un tendero, un escribano y un militar (con el $20 \%$, respectivamente). Alonso Vivar era un mercader de cacao y chocolate de notable proyección ${ }^{55}$, poseedor de "Una papelera de Madera de Palo de Rosa", dotada de varias navetas y "Secretos", y de otra papelera "de la misma Madera" y las mismas circunstancias. Ambos muebles estaban emplazados en la "Sala Pral"56. El escribano Manuel Estefanía, poseedor de una papelera de cedro, dotada de múltiples navetas y de "su secretto por dentro". La papelera estaba ubicada en la "Sala pral que cae al Jardín", es decir, en una estancia noble de la viviend $a^{57}$. Antonio Gonzalo del Río, comendador en el Hospital del Rey, disponía de una papelera de nogal con puertas "i Secretos de pino"58. El beneficiado en Medina de Pomar, y residente en Burgos, Bernardino Antonio Rosales poseía una papelera con cuatro navetas en la fachada y en la tapa seis arcos "y bajo de ellas un Secreto"59. El noble rentista y militar, coronel de infantería de los Reales Ejércitos, Miguel Antonio de la Torre Ribera disponía, entre los "Escriptorios y demás maderaxe", de dos papeleras del Norte, dotadas de dos navetas grandes y dos navetas medianas, que miran a la parte de afuera, "con su tapa y sus gavetas de parte de adentro, con diferentes divisiones y dos Secretos cada una"60. Los arcones con secreto, al 50\%, los hallamos, por una parte, en casa de la labradora María Rodrigo, viuda de Comián. Se trata de un arcón de roble con "su secreto" 61 y, por otra, en la vivienda del boticario Alfonso López Momediano, titular de un arcón de nogal provisto de "Dos Caxas de Secreto"62. El baúl se encontraba en manos de Bernarda Diego Rubio, viuda de un maestro platero Nicolás Martínez Huertos - un baúl forrado de cuero y por dentro con lienzo pintado "y su Secreto"_63. En casa del escribano del número Juan Antonio Herrera Tomé, el notario accedió, en primera instancia, "a uno de los quartos de su avitazión" y en "una Arca de Pino pequeña se enconttraron en unos Secretos, que incluía," 2.528 reales y 25 maraverdíes. "Después de lo cual [en segundo término], bajado al portal de la citada Casa pareció, bajo de una Peña de un poyo, que ay en él, un bote de

52 AHPB. José Guadilla. Legajo 7133/1 (11 de enero de 1788), folio 58.

53 AHPB. PN. Martín Robredo. Legajo 6966 (13 de enero de 1725), folio 21.

${ }^{54}$ AHPB. PN. Juan Antonio Fernández Guilarte. Legajo 6993 (26 de febrero de 1723), folio 117.

55 Sanz de la Higuera (2014a: 437-461).

${ }_{56}$ AHPB. PN. Feliciano Medel Prada. Legajo 7258/2 (28 de septiembre de 1781), folio 254.

57 AHPB. PN. Francisco Sanz Escolar. Legajo 7238 (17 de mayo de 1788), folio 38.

${ }^{58}$ AHPB. PN. Andrés Martín García. Legajo 8315 (27 de agosto de 1770), folio 77.

59 AHPB. PN. Francisco Villafranca. Legajo 7092/2 (25 de noviembre de 1746), folio 323.

60 AHPB. JM. Juan Antonio Fernández Guilarte. Legajo 976 (7 de mayo de 1751), folio 16.

${ }^{61}$ AHPB. PN. Lázaro Santamaría. Legajo 6865 (6 de junio de 1705), folio 395.

62 AHPB. JM. Andrés Miguel Varona. Legajo 928 (26 de abril de 1758), folio 61.

${ }^{63}$ AHPB. JM. Alonso Melo Peña. Legajo 983/7 (2 de diciembre de 1784), folio 12. 
hojalata y en él [múltiples] monedas" -unos 18.381 reales-, "que son las únicas monedas que parecieron en la Casa"64.

La documentación empleada en la articulación de estos análisis se polariza, en su totalidad, en los denominados inventarios de bienes, la inmensa mayoría de ellos post-mortem. La custodia de tales documentos está asociada, en primera instancia, al Archivo Histórico Provincial de Burgos, de donde procede el 93.9\% de los casos recopilados -el 93.9\% (869 documentos) en Protocolos Notariales y el 3.1\% (29 documentos) en Justicia Municipal-. En segundo término, se han localizado inventarios en el Archivo Capitular de la Catedral de Burgos -1.2\% (11 documentos)-. El Archivo Municipal de Burgos conserva otro 1\% (9 documentos), mientras que porcentajes más minoritarios se asocian a entidades no menos importantes pero con un menor volumen de inventarios en sus entrañas -del Archivo General de Palacio (Madrid) procede el $0.4 \%$ (4 documentos), del Archivo de la Diputación Provincial de Burgos el 0.2\% (2 documentos) y, a la postre, del Archivo Diocesano de Burgos (ADB) el $0.1 \%$ (1 documento)-. En los párrafos anteriores se ha señalado la existencia de algunas patologías documentales que enturbian, en la medida de lo posible, la definición de los "lugares" que servían para proteger el dinero en efectivo en los hogares burgaleses del XVIII. En gran parte 42 devienen de las carencias generadas por el quehacer de los escribanos, que no mencionaban el mobiliario contenedor del dinero o las estancias en que éstos se encontraban posicionados ${ }^{65}$.

En el tratamiento de las problemáticas de la presencia de dinero en efectivo en los interiores domésticos del Burgos del Setecientos y de los muebles y estancias en que sus propietarios los custodiaban, y detraían de las miradas ajenas, se ha usufructuado merced a la lectura y reflexión de un acervo bibliográfico no excesivamente prolijo, pero sí de notable calidad científica. Descuellan, en especial, las propuestas de Piera Miquel ${ }^{66}$, Aguiló-Alonso ${ }^{67}$, Álvarez Santaló ${ }^{68}$, Aguado de los Reyes $^{69}$, Noriega ${ }^{70}$ y Sanz de la Higuera ${ }^{71}$. La totalidad de este estudio queda al albur de las investigaciones sobre el mueble en la España del siglo $\mathrm{XVIII}^{72}$ y de las reconstrucciones de la cultura material en dicha centuria ${ }^{73}$. También es interesante

${ }^{64}$ AHPB. PN. Gregorio Padrones. Legajo 7138 (29 de septiembre de 1779), folio 673.

65 Resulta imprescindible, a este respecto, analizar con detalle las propuestas de Sobrado Correa (2003).

66 Piera Miquel (2012: 159-175).

67 Aguiló-Alonso (2011: 10-13).

68 Véanse, entre otras, Álvarez Santaló y García-Baquero (1980a, 1980b y 1998).

${ }^{69}$ Aguado de los Reyes (1994).

70 Noriega (2015).

71 Sanz de la Higuera (2013: 13-40, 2014: 461-478, 2015a, 239-283 y 2016: 85-121).

72 De entre las muchas opciones descuellan Echalecu (1957: 29-54), Junquera Mato (1990: 133161), Martínez Alcázar (2008: 219-232), Piera, Shelly y Marsal (2009) y Fernández Paradas (2013 y2016).

73 Véase la bibliografía referenciada en Sanz de la Higuera (2015b: 319-320). 
echar una mirada a los análisis que descubren cómo se desarrollaban las entidades de "ahorro" más rudimentarias a lo largo del Setecientos"

\section{Los muebles contenedores para ocultar el dinero en efectivo}

El interrogante esencial a resolver, llegados a este punto, es ¿En dónde guardaban el dinero en efectivo los burgaleses del Setecientos en los interiores domésticos de sus viviendas? ¿En qué muebles y en qué estancias? Previamente, es imprescindible, a mi juicio, plantear si existían, de fondo, estrategias, personales y/o colectivas, tendentes a conservar el dinero en la oscuridad de sus domicilios. ¿Las diferentes categorías socio-profesionales se comportaban de manera similar o existen profundas diferencias en la búsqueda de seguridad para sus alcancías?

\section{Gráfico 1}

Presencia de dinero en los hogares de Burgos

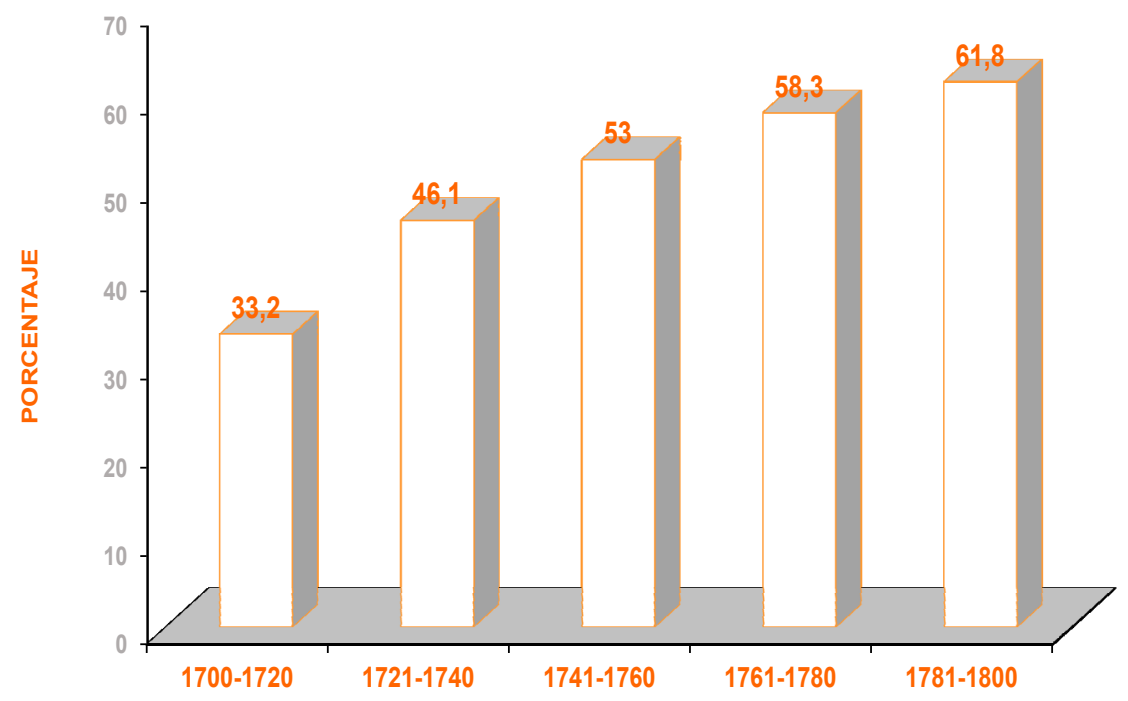

El devenir de la presencia del dinero en efectivo en los interiores domésticos burgaleses del Setecientos -véase Gráfico $1{ }^{75}$ nos induce a pensar que, a lo largo

74 Descuellan, entre otras muchas aportaciones, Blanco Anta (2016), Muñoz Serrulla (2007: 4566) y Cano Borrego (2014: 157-179).

75 Las diferencias porcentuales en el devenir de la presencia de dinero en efectivo en los hogares burgaleses del siglo XVIII al manejar 400 inventarios (2013) y 925 (2018) son, en la práctica, inexistentes. Las conclusiones a obtener no difieren en nada. Sanz de la Higuera (2013a: 23). 


\section{F.J. Sanz de la Higuera}

de dicha centuria, se hizo, año a año, más perentoria la necesidad -ante la inexistencia de entidades bancarias cercanas, y viables, donde depositar el dinerode proteger sus caudales de miradas y tentaciones aviesas. La escalada gradual y sostenida del porcentaje de presencia del dinero en las casas, desde el $33.2 \%$ de 1700-1720, el $46.1 \%$ de 1721-1740, el 53\% de 1741-1760, el 58.3\% de $1761-$ 1780 y del $61.8 \%$ de 1781-1800, estimula una privilegiada relación, retroalimentada, entre cultura material, dinero en efectivo y recuperación económica en la España, y en el Burgos, del Setecientos ${ }^{76}$.

\section{Gráfico 2}

Promedio de dinero en los hogares de Burgos
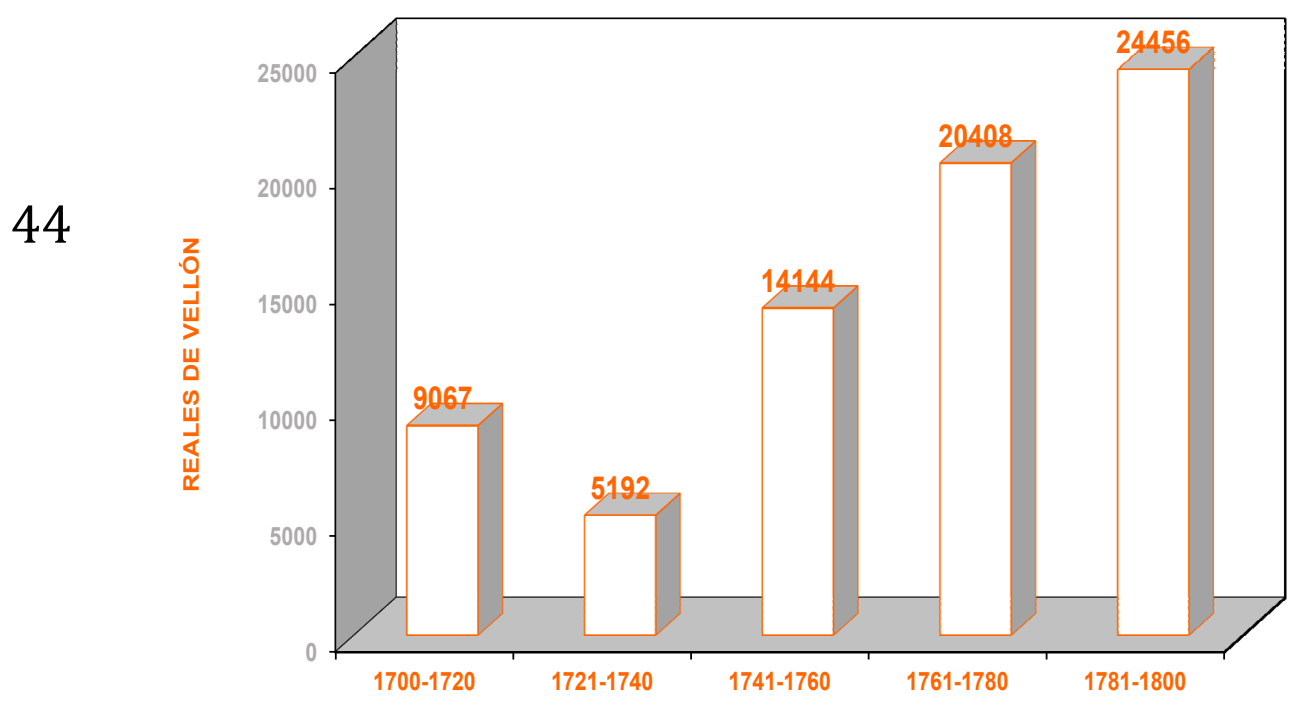

La mayor disponibilidad de dinero en las manos de los castellanos del XVIII -Gráfico 2- hacía preciso, a mi juicio, extremar las cautelas y solventar los miedos por su desaparición fraudulenta con sistemas de custodia, eficaces e imaginativos, que impidiesen su pérdida o extravío. Era ineludible tener el dinero cerca, en la intimidad del hogar, darlo a conocer únicamente a los más allegados y discriminar, en la medida de lo posible, entre la "buena moneda" y la "mala moneda", más atesorada o más en circulación, según fueran las necesidades profesionales o domésticas ${ }^{77}$. El bienestar y la seguridad de los componentes del hogar estaba ligado, en buena

76 Sanz de la Higuera (2016: 85-216).

77 Sanz de la Higuera (2013a: 13-40). 
parte, a la disponibilidad de dinero en efectivo. En palabras de Piera Miquel -que comparto en su totalidad- era perentorio disfrutar de "un espacio se custodiase en secreto (...) bajo medidas de seguridad que preservaran su integridad y evitaran su sustracción" ${ }^{178}$. La mayor y creciente disponibilidad de dinero en efectivo en los interiores domésticos en el Burgos del Setecientos no significa, empero, que los hogares burgaleses no se dieran al consumo. Se ha demostrado en múltiples ocasiones, los castellanos mejoraban substancialmente el acceso a canapés ${ }^{79}$, vidrieras ${ }^{80}$, menajes de iluminación ${ }^{81}$, menajes de cama $a^{82}$ y de mesa ${ }^{83}$ o relojes ${ }^{84}$, por traer a colación algunos pertrechos domésticos de singular interés.

\section{Tabla 1}

Presencia de dinero en efectivo en los hogares de Burgos (siglo XVIII)

\begin{tabular}{|l|c|c|c|c|c|c|c|c|}
\hline & \multicolumn{9}{|c|}{ Presencia de dinero } & $\begin{array}{c}\text { Promedio } \\
\text { dinero (1) }\end{array}$ & $\begin{array}{c}\text { Promedio patrimonio } \\
\text { (1) }\end{array}$ & CON \\
Profesiones & SI & $\%$ & NO & $\%$ & & $\begin{array}{c}\text { SIN } \\
\text { dinero }\end{array}$ & $\begin{array}{c}\text { \%DE/NF } \\
\text { (2) }\end{array}$ \\
\hline Hilanderas & 17 & 35.4 & 31 & 64.6 & 707 & 2.485 & 2.064 & 28.4 \\
\hline Jornaleros & 5 & 17.2 & 24 & 82.8 & 428 & 1.909 & 1.532 & 22.5 \\
\hline Labradores & 57 & 40.1 & 85 & 59.9 & 2.137 & 22.405 & 6.917 & 9.5 \\
\hline M/Artesanos & 96 & 55.5 & 77 & 44.5 & 7.558 & 30.097 & 7.207 & 25.1 \\
\hline Comerciantes & 62 & 66.7 & 31 & 33.3 & 14.841 & 133.654 & 40.250 & 11.1 \\
\hline Burócratas & 72 & 50 & 72 & 50 & 29.357 & 159.622 & 47.518 & 18.4 \\
\hline Servicio público & 46 & 46 & 54 & 54 & 4.453 & 30.068 & 11.558 & 14.8 \\
\hline Nobleza rentista & 42 & 46.1 & 49 & 53.9 & 29.718 & 167.889 & 96.038 & 17.7 \\
\hline Clérigos & 52 & 57.1 & 39 & 42.9 & 11.286 & 76.613 & 15.271 & 14.7 \\
\hline Militares & 6 & 42.8 & 8 & 57.2 & 138.361 & 383.503 & 19.594 & 36.1 \\
\hline BURGOS & 455 & 49.2 & 470 & 50.8 & 14.361 & 85.092 & 25.521 & 17.5 \\
\hline
\end{tabular}

(1) La totalidad de las magnitudes de dinero en reales de vellón.

(2) \% DE/NF: Índice porcentual del dinero en efectivo sobre el nivel de fortuna (patrimonio).

Fuente: AHPB. Protocolos Notariales. Múltiples Legajos.

En las próximas páginas, se infiere cómo, ya sean los hogares de los paupérrimos o los de la aristocracia laica y clerical, estaban involucrados en la hercúlea tarea de defender sus caudales. Es probable que quienes más "se esmeraron en proteger sus propiedades eran personas con capacidad adquisitiva limitada", dado que "en realidad aquello que tan ansiosamente protegían eran bienes relativamente poco

\footnotetext{
78 Piera Miquel (2012: 160).

79 Sanz de la Higuera (2013b: 139-161).

80 Sanz de la Higuera (2012: 1-33).

81 Sanz de la Higuera (2013c: 1-36).

82 Sanz de la Higuera (2009: 435-499 y 2011: 389-431).

83 Sanz de la Higuera (2013d: 107-130 y 2014c: 107-130).

84 Sanz de la Higuera (2013e: 23-47 y 2010: 23-49).
} 
importantes, aunque para ellos supusiera todo lo que habían conseguido agrupar"85. El dinero en efectivo del que disponían procedía de la sufrida fatiga diaria, del agotador trabajo cotidiano, mientras que para los más afortunados, perceptores de suculentos emolumentos y de ingentes rentas, el dinero era muy importante en sus existencias, pero los yacimientos de su procedencia eran bastante más flexibles, asequibles y fluidos. El peso relativo del dinero en efectivo sobre la totalidad de sus patrimonios, de sus niveles de fortuna -véase Tabla 1- era, en la práctica, mucho más abultado en las categorías socio-profesionales más paupérrimas, con la excepción, por una parte, de los labradores y hortelanos y, por otra, de los militares. Si trazamos un "Rubicón" porcentual discriminando por arriba y por debajo del $20 \%$, hilanderas, jornaleros y artesanos sobrepasan dicho umbral, de modo que el dinero en efectivo, con el 28.4, 22.5 y $25.1 \%$, respectivamente, supone para ellos un notable activo patrimonial, aún dentro de la modestia -véase Tabla 1-. Rompen con esa pauta las gentes del campo, quienes con un $9.5 \%$, patentizan la existencia de labradores y hortelanos poco capitalizados. Su riqueza se encuentra en las cosechas emergentes y los animales de labor. Los militares con dinero manejaban notables fortunas, de promedio, y el dinero en efectivo suponía, sobre la totalidad de sus patrimonios, un coeficiente muy significativo (36.1\%). Las demás categorías socio-profesionales se movían en umbrales por debajo del 46 susodicho $20 \%$, con guarismos más o menos similares -véase Tabla $1-$.

Es evidente que en una cultura de las apariencias efervescente y exigente, quienes más dinero tenían se aseguraban, también, la posesión de objetos más caros y deseados e impelían un deseo, a veces enfermizo, "de exhibirlos para hacer visible el éxito de su posesión"86. "La primera función -enfatiza Piera Miquel- que debían cumplir los contenedores destinados a objetos de valor era la de ponerlos a buen recaudo"87. La mayoría de la población tenía dificultades no sólo para disfrutar de múltiples bienes ${ }^{88}$ cuanto para proteger sus caudales y hasta sus propias estancias. Hasta el punto, como señala Pounds, de que "tenían casas con una puerta -a veces dos- que no podían cerrarse con total seguridad, y unas ventanas que, en el mejor de los casos, se cerraban con postigos. Era fácil entrar en ellas, y los robos eran frecuentes" 89 .

El devenir de los gráficos nos sugiere la existencia de circunstancias que hacían ineludible la necesidad de proteger el dinero en efectivo atesorado en los interiores domésticos, guardando en los muebles contenedores de las viviendas, y a ser posible en sus "Secretos" (sic), las monedas acumuladas. No todas las categorías socio-profesionales lo resolvían de la misma manera, porque cada una de ellas se enfrentaba a situaciones diferentes -véase Tabla 1-. A mi juicio, se puede establecer un patrón diferencial segmentando en tres umbrales de disponibilidad la presencia

\footnotetext{
85 Piera Miquel (2012: 160).

86 Piera Miquel (2012: 160).

87 Piera Miquel (2012: 160).

88 Moreno Claverías (2003: 207-245).

89 Pounds (1999: 246).
} 
de dinero en efectivo en los hogares burgaleses del Setecientos. En primera instancia, aquellos hogares en que dicha presencia se encontraba por debajo del $40 \%$, y cuyos promedios de monetario eran muy escasos. Se trata de los jornaleros ( $17.2 \%$ y 428 1/2 reales) y las hilanderas y pobres de solemnidad $(35.4 \%$ y 707 reales). En segundo lugar, los hogares que atesoraban dinero en efectivo entre el 40.1 y el $50 \%$ de los casos. Aquí nos topamos con los labradores y hortelanos $(40.1 \%$ y $2.137 \quad 1 / 2$ reales), los militares $(42.8 \%$ y $138.361 \quad 1 / 2$ reales), los profesionales de los servicios públicos ${ }^{90}$ (46\% y 4.453 1/2 reales de vellón), la nobleza rentista, dirigente del Concejo y terrateniente (91) $(46.1 \%$ y 29.718 1/2 reales de promedio) y los burócratas ${ }^{91}$ ( $50 \%$ y 29.357 reales). La ciudad en su conjunto, merced a los inventarios de bienes recopilados, se sitúa en un empate técnico entre los hogares que sí atesoraban dinero en efectivo, el $49.2 \%$, y aquellos en los que el escribano no descubrió absolutamente nada de dinero (50.8\%). En último término, descuellan los hogares de las categorías socio-profesionales con mayor acceso, y disponibilidad, de dinero en efectivo, es decir, los artesanos, los clérigos y los comerciantes. Los artesanos atesoraban caudales en sus interiores domésticos en el $55.2 \%$ de las viviendas, si bien su promedio es bastante reducido, con 7.622 reales de vellón. Los eclesiásticos guardaban dinero en efectivo en el $57.1 \%$ de los hogares recopilados, con un promedio interesante (11.286 reales de vellón). A la postre, la categoría socio-profesional más prolífica en lo tocante a la manejabilidad de caudales en efectivo era la de los comerciantes. En el $66.7 \%$ de sus casas se inventarió dinero, con un promedio notorio, aunque no excesivamente rotundo $(14.841 \text { reales })^{92}$.

Disponer de dinero o no en los hogares establece un contraste notorio entre sus niveles de fortuna, siempre más elevados para quienes gozaban de poco o mucho dinero en efectivo. La diferencia es reducida, casi anecdótica, en las categorías socio-profesionales más paupérrimas, con un balance patrimonial muy cercano entre unos y otros -estamos hablando de 400 reales más o menos-. Empero, en los demás casos -véase Tabla 1- el contraste es muy voluminoso. En especial, entre los militares, los eclesiásticos ${ }^{93}$ y los artesanos. Resulta gravoso para los labradores, los comerciantes ${ }^{94}$, los burócratas y los profesionales de los servicios públicos. Queda,

90 Se agrupan bajo tal denominación aquellos hogares cuyos quehaceres profesionales están ligados al transporte, los mesones y posadas, las obligaciones de suministro urbano y los profesionales de la sanidad (médicos, boticarios, cirujanos, barberos, ...).

91 Escribanos y procuradores del número, abogados, empleados de Hacienda y profesionales de las administraciones eclesiásticas.

92 Los comerciantes eran dados a múltiples "...estímulos de atesoramiento de metales preciosos y máximo cuando, con cierta frecuencia, los inventarios se refieren a bolsas de piel y cofres con monedas de oro y plata". Álvarez Santaló, L. C. y García-Baquero González, A. (2008: 282).

93 Se contempla la existencia de varios rangos de eclesiásticos en función de sus niveles de renta y de fortuna: clero bajo o proletarizado, clero parroquial o medio y clero alto o capitular (Cabildo Catedral) y clero de instituciones especiales (Hospital del Rey y Real Monasterio de Las Huelgas).

94 Se anotan bajo el epígrafe "comerciantes" los mercaderes de paños y sedas o comerciantes al por mayor y los tenderos o mercaderes al por menor o de joyería y especiería. 
no obstante, más atenuado entre los nobles rentistas ${ }^{95}$, categoría en la que los hogares con dinero en efectivo únicamente duplican sus niveles de fortuna con respecto a los hogares sin dinero en efectivo.

La necesidad de proteger el dinero en los hogares ien qué manera se sustancia en lo tocante al mobiliario contenedor en el Burgos del Setecientos? El requisito imprescindible es que el escribano, en sus quehaceres deambulatorios por el interior de los domicilios para llevar a cabo la tasación de los enseres y pertrechos, enfatizara, de forma específica en la confección del inventario de bienes, en dónde se encontraba el dinero, y, a ser posible, en qué estancia de la casa. Lamentablemente, tales circunstancias no sucedieron en todas las oportunidades posibles. En este sentido, la situación es lacerante. Únicamente tres de los escribanos nos ofrecieron, en el $100 \%$ de los inventarios por ellos redactados, una constancia cierta de en dónde, en qué mueble, estaba el dinero en efectivo ${ }^{96}$. El $9.2 \%$ de los escribanos sólo lo hizo entre el 0.1 y el 10\% de las ocasiones. El 29.3\% en el umbral $10.1-30 \%$ y un $13.8 \%$ en el segmento $30.1-99.9 \%$. Descuella, en especial, el escribano del número y del Cabildo Catedral Juan Antonio Fernández Guilarte $^{97}$. En el 28.8\% (17 documentos) de los 59 inventarios recopilados dejó constancia explícita de en qué mueble apareció el dinero en efectivo.

Con tales perspectivas, no en todas las categorías socio-profesionales disponemos de una información similar -véase Tabla 2-. Para los labradores y hortelanos (5.3\%), la nobleza rentista (14.3\%), los artesanos y militares (16.7\%, respectivamente), los tenderos (17.5\%) y los profesionales de los servicios públicos (21.7\%) los escribanos nos suministran información sobre la localización del dinero en menos del $30 \%$ de los hogares. Mejor orientados vamos a estar en los hogares de los profesionales de las administraciones eclesiásticas $(40.9 \%)$, las hilanderas y pobres de solemnidad $(41.2 \%)$ y los procuradores y abogados (47.4\%), con umbral significativo del 30 al $49.1 \%$ de las ocurrencias. Sin duda, es con los eclesiásticos (51.9\%), escribanos (52.9\%), profesionales de la administración de Hacienda (53.8\%) y los comerciantes al por mayor, de paños y sedas (54.5\%), donde los análisis serán más certeros, al disponer de un porcentaje de hogares con indicación de dinero y mueble contenedor correctamente especificado por los escribanos.

95 Bajo esa denominación se inscriben los aristócratas burgaleses, terratenientes, rentistas y, en la mayoría de las ocasiones, alcaldes y regidores perpetuos del Consejo o Ayuntamiento.

96 Únicamente disponemos para ellos de un legajo con distintos protocolos. Se trata de Julián Álvarez, José Julián Villar y Domingo Loyola.

97 Juan Antonio Fernández Guilarte 1718-1768, Legajos 6988-7033) sucedió a su padre, José Fernández Guilarte (1680-1717, Legajos 6882-6908) en la escribanía del número y del Cabildo Catedral, y, a su vez, fue reemplazado por Alonso Melo Peña (1767-1806, Legajos 7219-7233). 
Tabla 2

Presencia de dinero en los hogares burgaleses (siglo XVIII)

\begin{tabular}{|l|c|c|c|c|c|}
\hline & $\begin{array}{c}\text { Total } \\
\text { Profesiones }\end{array}$ & $\begin{array}{c}\text { Hogares } \\
\text { con dinero }\end{array}$ & $\%$ & \multicolumn{3}{c|}{$\begin{array}{c}\text { Muebles } \\
\text { con dinero }\end{array}$} & $\%$ \\
\hline Hilanderas & 48 & 17 & 35.4 & 7 & 41.2 \\
\hline Jornaleros & 29 & 5 & 17.2 & 0 & 0 \\
\hline Labradores & 142 & 57 & 40.1 & 3 & 5.3 \\
\hline M/Artesanos & 173 & 96 & 55.5 & 16 & 16.7 \\
\hline Comerciantes & 23 & 22 & 95.6 & 12 & 54.5 \\
\hline Tenderos & 70 & 40 & 57.1 & 7 & 17.5 \\
\hline Escribanos & 32 & 18 & 56.2 & 9 & 52.9 \\
\hline Procuradores & 36 & 19 & 52.8 & 9 & 47.4 \\
\hline Admón. Hacienda & 33 & 13 & 39.4 & 7 & 53.8 \\
\hline Admón. Eclesiástica & 43 & 22 & 51.2 & 9 & 40.9 \\
\hline Servicios públicos & 100 & 46 & 46 & 10 & 21.7 \\
\hline Nobleza rentista & 91 & 42 & 46.1 & 6 & 14.3 \\
\hline Clérigos & 91 & 52 & 57.1 & 27 & 51.9 \\
\hline Militares & 14 & 6 & 42.8 & 1 & 16.7 \\
\hline BURGOS & 925 & 455 & 49.2 & 123 & 27 \\
\hline
\end{tabular}

Fuente: AHPB. Protocolos Notariales. Múltiples Legajos.

Los muebles en los que "parezieron" (sic) los dineros en efectivo de los burgaleses del Setecientos a lo largo del siglo XVIII pueden ser clasificados, a mi entender, en cuatro tipos, en función de sus peculiaridades. En primera instancia, los muebles contenedores de carácter "horizontal", es decir, arcas, arcones, baúles, cofres y cajones. En segundo término, los muebles ubicados en las tiendas y trastiendas. En tercer lugar, los muebles "verticales" -escritorios, papeleras, contadores y archivos-. A la postre, y como cuarta opción, el mobiliario, a este respecto del guardar dinero en efectivo, más extemporáneo y poco frecuente -la cama y la mesa-. En la Tabla 3 se aprecian los índices de aparición de dinero y muebles tanto a nivel global como en lo tocante a qué sucedía en cada una de las categorías socio-profesionales.

La tipología más utilizada por los hogares burgaleses en que disponemos simultáneamente de dinero y de mueble contenedor fue la señalada en tercer lugar, los muebles "verticales", con el $60.2 \%$ en su conjunto. No parecen en las casas de las hilanderas y pobres de solemnidad y, por el contrario, fueron el $100 \%$ en los hogares de las gentes del derecho -procuradores del número y abogados-. Los escribanos (88.9\%), los profesionales de Hacienda (85.7\%), los clérigos $(77.8 \%)$ y los profesionales de las administraciones eclesiásticas (77.7\%) los usaron, en sus estrategias de custodiar sus caudales, como su opción preferente. Los comerciantes al por mayor (66.6\%) y los profesionales de los servicios públicos y la nobleza rentista -con el $50 \%$ en ambos casos- recurrían a tales muebles con especial significación, siendo su primera opción. En labradores (33.3\%), artesanos (31.2\%) y tenderos (14.3\%) el recurso al mueble "vertical" es minoritario. 
Pecvnia, núm. 24, 2021, 33-66

F.J. Sanz de la Higuera

Tabla 3

Tipos de muebles contenedores para la protección del dinero en efectivo

\begin{tabular}{|c|c|c|c|c|c|c|c|c|c|c|}
\hline \multirow[b]{2}{*}{ Profesiones } & \multicolumn{10}{|c|}{ Muebles contenedores con dinero en efectivo en su interior } \\
\hline & $\begin{array}{c}\text { Tipo I } \\
\text { (1) }\end{array}$ & $\%$ & $\begin{array}{c}\text { Tipo II } \\
\text { (2) }\end{array}$ & $\%$ & $\begin{array}{c}\text { Tipo III } \\
\text { (3) }\end{array}$ & $\%$ & $\begin{array}{c}\text { Tipo IV } \\
\text { (4) }\end{array}$ & $\%$ & Total & $\%$ \\
\hline Hilanderas & 6 & 85.7 & 1 & 14.3 & 0 & 0 & 0 & 0 & 7 & 100 \\
\hline Jornaleros & 0 & 0 & 0 & 0 & 0 & 0 & 0 & 0 & 0 & 100 \\
\hline Labradores & 1 & 33.3 & 1 & 33.3 & 0 & 0 & 1 & 33.3 & 3 & 100 \\
\hline M/Artesanos & 9 & 56.2 & 1 & 6.3 & 1 & 6.3 & 5 & 31.2 & 16 & 100 \\
\hline Comerciantes & 2 & 16.7 & 0 & 0 & 2 & 16.7 & 8 & 66.6 & 12 & 100 \\
\hline Tenderos & 6 & 85.7 & 0 & 0 & 0 & 0 & 1 & 14.3 & 7 & 100 \\
\hline Escribanos & 1 & 11.1 & 0 & 0 & 0 & 0 & 8 & 88.9 & 9 & 100 \\
\hline Procuradores & 0 & 0 & 0 & 0 & 0 & 0 & 9 & 100 & 9 & 100 \\
\hline $\begin{array}{l}\text { Admón. } \\
\text { Hacienda }\end{array}$ & 1 & 14.3 & 0 & 0 & 0 & 0 & 6 & 85.7 & 7 & 100 \\
\hline $\begin{array}{l}\text { Admón. } \\
\text { Eclesiástica }\end{array}$ & 2 & 22.2 & 0 & 0 & 0 & 0 & 7 & 77.7 & 9 & 100 \\
\hline $\begin{array}{l}\text { Servicios } \\
\text { públicos }\end{array}$ & 5 & 50 & 0 & 0 & 0 & 0 & 5 & 50 & 10 & 100 \\
\hline Nobleza rentista & 2 & 33.3 & 1 & 16.7 & 0 & 0 & 3 & 50 & 6 & 100 \\
\hline Eclesiásticos & 6 & 22.2 & 0 & 0 & 0 & 0 & 21 & 77.8 & 27 & 100 \\
\hline Militares & 1 & 100 & 0 & 0 & 0 & 0 & 0 & 0 & 1 & 100 \\
\hline BURGOS & 42 & 34.2 & 4 & 3.2 & 3 & 2.4 & 74 & 60.2 & 123 & 100 \\
\hline
\end{tabular}

(1) Arca, arcón, baúl, cajón y mixtos (cofre y arca, cofre y baúl, cofre y mesa, arca y escritorio, ...)

(2) Cama y mesa

(3) Armario, escritorio y mostrador de tiendas mercantiles

(4) Escritorio, papelera, contador y archivo (cajón) y papelera y calzón

Fuente: AHPB. Protocolos Notariales. Múltiples Legajos.

Algunos ejemplos resultan paradigmáticos como modelos paradigmáticos de lo sucedido en los interiores domésticos del Burgos del Setecientos. De entre las muchas posibles opciones, se van a citar un surtido elenco de inventarios a modo de breve vórtice demostrativo. El comerciante de paños y sedas Francisco Sáinz de Viniegra ocultaba su dinero en efectivo "En un Escriptorio Salamanquino que se alla en un quartito detrás de la Alcoba deel quarto pral, donde murió (...), cuia llave se allava recojida, [y] se hallaron las especies de monedas siguientes...", por un total de 48.393 reales de vellón. A ello se añaden otros 2.985 reales del "Dinero que se alló en la tienda"98. En el caso del también mercader de paños y sedas Tomás

98 AHPB. PN. Francisco Villafranca. Legajo 7098/1 (16 de diciembre de 1768), folios 17-18. Es los comerciantes, en especial los de paños y sedas, al por mayor, es notaria la diversificación, estratégica, entre el dinero en efectivo guardado arriba (estancias de intimidad) y abajo (tienda y trastienda). 
Martínez de Velasco los parámetros son casi idénticos a los anteriores, con 38.627 reales y 26 maravedíes que "se encontraron en el escriptorio que estaba en la Alcoba donde murió el Difunto en diferentes monedas de oro y plata", más 2.800 reales "que en diferentes monedas se hallaron en dha tienda"99. Del escribano del número Agustín Hurtado de Saracho, y del "Dinero que pareció existente", se indica que en "el escriptorio Salamanquino que ba puesto por principio deste Ymbentario, en dos Nabetas deel, se encontraron" 13.556 reales y 28 maravedíes, a lo que se añade, más dinero en "los baules y arcones, y en el de tres llabes barreteado se allaron diversos talegos $y$ en todos ellos"100. En e inventario del maestro sastre Juan Caballero "se abrió por mí el Ssno una Nabetas del Escrittorio en que se pusieron todas las llabes que recoji, reservando en mí la de dho escrittorio, y en él parecieron" múltiples monedas"101. Al beneficiado en San Lorenzo y capellán de la Congregación de la Real Juan Antonio Díez Gómez se le anotaron 146 reales de vellón que dijeron "haberse encontrado en diferentes monedas en la Nabeta de un escriptorio del Quarto del dormitorio"102. Al también eclesiástico, beneficiado en San Lesmes, Lesmes Bravo Pascual pertenecían 1.653 reales "que parecieron en diferentes monedas de oro y plata en las Navetas del escriptorio o bufete que existía en el quarto del Dormitorio" ${ }^{103}$. En casa de José Barrio Mirón, canónigo del Cabildo Catedral, "Dichos testamentarios Dijeron que abiendose Reconozido los Escriptorios de Arriba -dos escritorios de palo santo y marfil con mesas de nogal- Parezieron aber en ellos Seiscientos y Setenta y tres Rs de Vellón en oro, Platta, Calderilla y ochabos"104. En las estancias del beneficiado en San Lorenzo y capellán del número en la Catedral José del Cerro se descubrieron 1.998 reales "en las navetas del escriptorio y otras partes donde se discurría podía averlo". Se trata de un escritorio de nogal cubierto de ébano y perfilado en hueso, dotado con 14 navetas, ubicado en el "Primero Quarto", a la postre el dormitorio principal ${ }^{105}$. Al capellán del número de la Catedral José Ruiz se le "abrieron un Escritorio Salamanquino y las Nabetas de un bufete de nogal [ubicado en el "Quarto Pral"] en donde sólo se hallaron novecientos y veinte y Cinco Rs con barios papeles (...) los que volbieron a Cerrar y recojieron las llaves de dho escriptorio y Nabetas, como también las de los Baúles y Cofres que en dha Casa se hallaron..." ${ }^{106}$. El más tarde conocido como bargueño, el escritorio, es el mueble por antonomasia, el más usado como "caja de caudales" $y$, a la postre, como el mueble contenedor del máximo prestigio social. Desarrollada esta tipología de mueble a partir del siglo XVI, estaba pensada "especialmente para la guarda de documentos, dinero y objetos de valor (...) mueble fundamental de los interiores españoles de los siglos XVI y XVII", si bien en el XVIII aún tenido muy

99 AHPB. PN. Bernardo Alonso Illera. Legajo 7194/6 (23 de junio de 1788), folio 2.

100 AHPB. PN. Isidro Simancas. Legajo 7070 (13 de marzo de 1751), folios 197, 201 y 258. En total, 115.933 reales y 4 maravedíes.

101 AHPB. PN. Manuel Peña. Legajo 7111 (19 de diciembre de 1762), folio 663.

102 AHPB. PN. Juan Antonio Fernández Guilarte. Legajo 7030 (7 de enero de 1765), folio 18.

103 AHPB. JM. Bernardo Alonso Illera. Legajo 983 (19 de junio de 1781), folio 13.

104 AHPB. PN. Juan Antonio Fernández Guilarte. Legajo 6988 (12 de mayo de 1718), folio 241.

105 ACCB. Juan Antonio Fernández Guilarte. Libro 98 (3 de enero de 1735), folio 702.

106 AHPB. PN. Ángel Arnaiz. Legajo 7173 (7 de abril de 1777), folio 466. 
predicamento 107. "Su estructura organizaba -enfatiza Piera Miquel- por múltiples cajones y compartimentos permitía ordenar todos aquellos objetos pequeños que se necesitaba esconder". Su uso era privado "y se solía colocar [como queda demostrado] en el estudio, el dormitorio o en otras estancias personales del propietario, [aunque] el diseño estaba pensado igualmente para poderse trasladar con facilidad"108. Es probable que, en efecto, "Llegados al siglo XVIII, el escritorio [perdiera] rápidamente protagonismo, [cuando] el modelo de interior francés que entra de la mano de la dinastía borbónica se extendió por el territorio español con una nueva propuesta de organización de los espacios"; empero, como indica la propia Piera Miquel, "el hombre de la llustración [y el burgalés del XVIII, quizá apegado a lo antiguo, obsoleto] siguió necesitando contenedores donde guardar objetos de valor" -en especial dinero en efectivo-, "muebles que incluían secretos que alejaban algunas pertenencias de la vista pública"109.

Por lo que respecta a las papeleras, véanse las ocurrencias sucedidas en varias casas de la ciudad. Descuella la del clérigo Juan Francisco Guzmán, capiscol, dignidad y canónigo en el Cabildo Catedral de Burgos ${ }^{110}$, cuya estrategia protectora se materializaba en la ocultación de 1.202 reales y 12 maravedíes "que parecieron en una Navetas de la papelera, los tres [doblones de a 8] en un Papel y el otro suelto", 52 a lo que se añadían 360 reales "en una Bolsita de Seda Azul" y 4.000 reales "que se hallaron en un Cajón Suelto". Se trata de "Una Papelera de Nogal hecha a la Moderna, vien Tratada, con sus Nave tas y Cajones y herrajes Dorados". Dicha papelera residía en los "Quartos Prales en que murió", en compañía de "Quadros, trastos y otros ajuares". Juan Francisco no disponía de escritorios y sí de varios baúles, además de la mencionada papelera, ubicados en los citados cuartos, su dormitorio, y en el "Quarto Segundo de abajo" -preñado con 5 baúles grandes- ${ }^{111}$. De forma similar al anterior, el beneficiado en Santa Águeda José Pereda Arce no poseía ningún escritorio, lo cual se obligaba, descartadas las arcas, a proteger sus 3.583 reales y 7 maravedíes en "los cajones y Navetas de la papelera"112. El escribano receptor del Real Adelantamiento Francisco López de Séneca disponía, en la "Sala Segunda" de su hogar de un escritorio salamanquino, pero prefería, en aras de la seguridad de su dinero, depositar los 5.100 reales que atesoraba, "y se encontraron existentes en especie de oro y plata, en la papelera que usaba dicho don Francisco", ubicada en el "Quarto de Despacho", papelera de pino pintada de negro y encarnado ${ }^{113}$. El obligado de carnes y licores Manuel Cortés Moreno era poseedor de una papelera de nogal con pie de caoba "que es donde se pusieron en Custodia las llabes, que está en el Tercer Quarto". Allí reposaban 502 reales "que se hallaron dentro de dha papelera en monedas de oro, plata y Vellón, que son los

\footnotetext{
Piera Miquel (2012: 164) y Maruri Villanueva (1990: 127).

Piera Miquel (2012: 165).

109 Piera Miquel (2012: 170).

110 Sanz de la Higuera (2013f: 219-242).

111 AHPB. JM. Alonso Melo Peña. Legajo 983/2 (16 de septiembre de 1778), folios 1, 5-6 y 8-11.

112 AHPB. PN. Jacinto Álvarez. Legajo 7119/2 (16 de enero de 1766), folio 34.

113 AHPB. PN. Jacinto Álvarez. Legajo 7122/1 (10 de enero de 1771), folio 389.
} 
Únicos que manifestó dha Da Cathalina haver en la Casa"114. El aristócrata Francisco Melgosa, regidor perpetuo en el Concejo y noble rentista, tenía varios escritorios en el "Salón [oratorio] a la Calle" y en el "Quarto Dormitorio al Río" pero prefería guardar su dinero en efectivo "en dos papeleras que estaban en la Alcoba deel difunto (...)" en múltiples monedas diferentes, junto con los papeles importantes ${ }^{115}$. Casilda Gallo y Miguel de la Moneda, miembros también de la élite aristocrática más rancia de la ciudad, se decantaron igualmente por la papelera, ubicada en el "Quarto Gabinete de Papeles", si bien allí mismo nos topamos con dos prodigiosos escritorios "de Nápoles, de ébano y marfil" -tasados en 3.000 reales-. En la susodicha papelera, y en sus múltiples cajones, se encontraron diferentes papeles y asimismo varias bolsitas preñadas de dinero en efectivo, a más de 178 reales que "parezieron en las faltriqueras de uno de los calzones del dho don Miguel"116.

Para traer a colación el contador disponemos del magnífico inventario post-mortem del administrador general de la Renta del tabaco José Antonio Gonzalo del Río. Su inmensa fortuna estaba guardada en "un contador [de pino, ubicado en el "Tránsito al Despacho"], de que tenía llave (...) y habiéndose habierto y sacado diferentes talegos y contado las monedas que en ellos había" se obtuvo una cifra realmente astronómica para el Burgos del Setecientos. José Antonio era poseedor de varios escritorios en su "Gabinete", e incluso en la "Antesala", o una papelera en el "Despacho" y otra en la "Sala Pral", pero su confianza se materializaba en el citado contador, lejos, por supuesto, de los baules del citado "Gabinete" o del "Pasadizo a la Sala"117.

En segundo término, fueron los muebles "horizontales" los lugares más idóneos, con un 34.2\% de aparición. Los procuradores y abogados no recurrieron a ellos en ninguna ocasión. Los militares al 100\%. Las hilanderas y los tenderos, con el $85.7 \%$, hicieron de tales muebles su opción esencial. En un término intermedio se movían los artesanos (56.2\%) y los profesionales de los servicios (50\%), sin negar, en absoluto, la importancia de este comportamiento. En las demás categorías socioprofesionales esta opción es notable pero no siempre la más significativa -los labradores y la nobleza rentista al $33.3 \%$, los clérigos y los profesionales de las administraciones eclesiásticas al $22.2 \%$, los comerciantes al por mayor al $16.7 \%$, los empleados de Hacienda al $14.3 \%$ y los escribanos, en último lugar, con el $11.1 \%-$.

El maestro tejedor José Martínez desechó el arcón o el cofre y se decantó por el arca, de modo que en su vivienda "Primeramente se reconoció una Arca que se halla en un quarto entrando en la Sala pral a mano dra, y en la que manifestó la referida (...) custodiaba su difunto marido los dineros, y se halló existir" 9.841

114 AHPB. PN. José Guadilla. Legajo 7131 (20 de octubre de 1780), folios 915-916.

115 AHPB. PN. Santiago Romo. Legajo 6983 (17 de agosto de 1744), folios 537-540.

116 AHPB. PN. Santiago Romo. Legajo 6983 (21 de octubre de 1744), folio 135.

117 AHPB. PN. Nicolás Martínez Vivanco. Legajo 7150 (3 de siembre de 1768), folios 175-176. 
reales $^{118}$. $\mathrm{M}^{\mathrm{a}}$ Cruz Clemente, viuda del maestro tajador de carne Chabarría, también confiaba en ese mueble, incluso más que en el escritorio de su propiedad. 11.827 reales "parecieron mettidos en un ttalego y en una de las dhas [tres] Arcas"119. El maestro de obras Francisco Bastigueta apostaba igualmente por el arca, aunque tenía donde elegir -baúles, cofres, escritorios, archivos, armarios, etcétera-. Sus $2.7091 / 2$ reales reposaban habitualmente en un arca, en doblones de a 8 y en escudos de oro de a $20^{120}$. La mercader de paños y sedas Manuela Laredo murió poseyendo 64.860 reales "En dinero Sonante y tres Vales $R s$ de a Seiscientos Pesos con sus intereses" que guardaba en el arca de nogal de la tienda -"En ella hay lo siguiente"-, junto con los dos baúles "en que están muchos de los citados efectos [comerciales]"121.

"Phelix" Sánchez de Valencia, administrador general de las Rentas Reales -léase Hacienda borbónica-, atesoraba, en el interior de su vivienda, 57.000 reales en coronillas. La descripción del proceso de tasación es emocionante: "Haviéndose abierto un Arcón constituído para Archibo ${ }^{122}$, localizado en la "Sala para el Estrado", "se encontró dentro una Arquita con su llabe en la que se hallaron [las coronillas de oro] puestas en sus cucuruchos de papel, de a mil Rs cada uno", más 2.750 reales en monedas de plata"123. Una mayor modestia descubrimos en casa del zapatero Antonio García, al que "se encontró en un Arcón una Cestilla de minbres con Setecientos Setenta y tres rs, en oro en una bolsita mil trescientos Setenta $y$ Cinco rs, en Una Caxa de oxa de lata quinientos Sesenta y quatro"124. La viuda del maestro batidor de oro Andrés Pérez Arroyo, María Valdivielso, ocultaba 6.000 reales "que se hallaron en un Arcón de nogal, puesto en un talego en monedas"125. La cercanía al lecho nocturno primaba en la estrategia del canónigo catedralicio Santiago Diez Guerra, para quien "habrieron un Arcón que está detrás de la Cama en que murió dho difunto y en él Parezieron diferentes Monedas de oro y Plata"126.

El recurso a cofres y baúles fue muy minoritario en esta singladura monetaria. Resalta el ejemplo de la hilandera María Garay, viuda del maestro cabestrero de Tomás García Vezo, a quien se adjudicaron 231 reales "que en pesos fuertes y otras monedas de plata se encontraron en un baúl cerrado con dos llaves, envueltos en un pedazo de lienzo viejo"127. Fue preferido el baúl a los arcones y arcas que poblaban sus reducidos interiores domésticos. Similar opción tomó el tendero Juan

118 AHPB. PN. Antonio Rafael Pérez. Legajo 7269/6 (30 de abril de 1779), folio 4.

119 AHPB. PN. Diego Fernández Cormenzana. Legajo 7074 (14 de enero de 1734), folio 46.

120 AHPB. PN. Juan Antonio Fernández Guilarte. Legajo 7022 (28 de agosto de 1757), folio 539.

121 AHPB. PN. Julián Álvarez. Legajo 7267 (6 de septiembre de 1799), folio 26.

122 "Un arcón de nogal de dos baras de largo con barias aperturas en la tapa para echar moneda".

123 AHPB. PN. José Guadilla. Legajo 7131 (27 de febrero de 1778), folio 725.

124 AHPB. PN. Gregorio Padrones. Legajo 7136 (21 de diciembre de 1764), folio 261.

125 AHPB. PN. Manuel Iturriaga. Legajo 7144/2 (4 de noviembre de 1757), folio 666.

126 AHPB. PN. Alonso García Manrique. Legajo 6811 (25 de octubre de 1713), folio 377.

127 AHPB. PN. Juan Antonio Fernández Guilarte. Legajo 7033 (15 de marzo de 1768), folio 314. Véanse también 20 1/2 reales "que se hallaron envueltos en un trapo, en un baúl, medios reales de plata y uno de a dos reales y medio". 
Martínez Céspedes. Las autoridades efectuaron el "rejistro de dos Baúles que se hallan en el entresuelo de la nominada Casa y de otros Arcones que hai en ella y sólo en uno de los Citados Baúles se halló un Bolsillo, el Qual sacó (...) y contádose por éste los dineros que en él había"128. El canónigo y penitenciario en el Cabildo Catedral Pedro Terán optó por salvaguardar 17.853 1/2 reales "en diferentes Cofres y Baúles privativos y propios del enunciado y ottras parttes donde se discurría podía aver algún Dinero"129. El también clérigo Juan Salazar Vega, capiscol, dignidad y canónigo catedralicio, ocultaba 17.481 reales en monedas de oro y plata "en el cofrecito ${ }^{130 "}$ en que además [tenía] algunas Alajas de plata"131.

El procurador del número Domingo Ortúzar se decantó no por los escritorios, los baúles, los cofres o los arcones que poblaban su inmensa residencia sino por "Un Caxón de nogal con tres tiradores y lo interior de pino con su errage", que tenía dispuesto en el "Quarto Primero" o principal, para salvaguardar sus dineros ${ }^{132}$. No olvidemos que el Abad de San Quirce, dignidad y canónigo en el Cabildo Catedral Ramón Larrínaga apostaba por algo similar, como señalamos anteriormente ${ }^{133}$.

Los muebles de tiendas y trastiendas -que suponen, desde la perspectiva global, el $2.4 \%$ de las ocurrencias-, están asociados, en la práctica, a los comerciantes $(16.7 \%)^{134}$ y a los artesanos (6.3\%). En las tiendas en las que materializaban sus negocios mercantiles, algunos comerciantes, como, por ejemplo, Faustino Vinuesa, encajaban su dinero en efectivo, 11.000 reales en su caso, en una papelera de cedro y el mostrador con trampas ${ }^{135}$. El también comerciantes de paños y sedas Agustín del Castillo protegía 4.829 reales "que en diferentes Monedas de plata y oro se hallaron en la nabeta de la mesa de la Tienda y un escriptorio"136. El maestro cerero Antonio Buitrago tenía "El dinero en el armario de entretienda en quatro talegos de monedas" (...) gran porzión de moneda de oro [y] platta (...) y ottras cossas de grande ynporttanzia"137.

La cama y una mesa fueron usados en un número de ocurrencias muy reducida, el $3.2 \%$ en su conjunto, y se han localizado en inventarios de labradores (33.3\%),

128 AHPB. PN. Gregorio Padrones. Legajo 7140 (15 de febrero de 1790), folio 335.

129 ACCB. Juan Antonio Fernández Guilarte. V1 (14 de mayo de 1757), folio 164.

130 Un cofre pequeño de curso negro, localizado en el "Quarto pequeño" de su casa, en la disponía de varios escritorios - "Quarto antesala" - e incluso en el susodicho "Quarto pequeño".

131 AHPB. PN. Domingo Ibáñez Varona. Legajo 6935 (25 de febrero de 1723), folios 95 y 102. Añádanse 474 r y 22 m que se indica "haver parecido en el tirador de la mesa del quarto pequeño".

132 Unos 9.5412 reales "en varias Monedas de oro y plata". AHPB. PN. Ángel Arnaiz. Legajo 7171 (15 de septiembre de 1772), folio 225.

133 AHPB. PN. Jacinto Álvarez. Legajo 7268 (16 de diciembre de 1773), folio 33.

134 Que suponen el $66.6 \%$ de este recurso.

135 AHPB. PN. Félix Martín García. Legajo 8328/4 (12 de marzo de 1799), folio 11.

136 AHPB. PN. Francisco Sanz Escolar. Legajo 7237 (30 de noviembre de 1791), folio 34.

137 AHPB. PN. Lázaro Santamaría. Legajo 6866/1 (23 de marzo de 1706), folios 447 y 453. 
nobles rentistas (16.7\%), hilanderas (14.3\%) y artesanos (6.3\%). Descuella Brígida Calleja, labradora, poseedora de 140 reales "que dentro de una nabeta de [una] Mesa estaban y constan de la diligencia de Recojimiento de llabes"138. Al maestro de obras Francisco de Bastigueta se le localizaron 225 reales y 30 maravedíes que "dijeron haber encontrado en la gaveta de una mesa que está en el cuarto en que avitaba y dormía"139. Muy atípico era igualmente ${ }^{140}$ el clérigo Pedro Antonio Fernández, teniente de cura en la parroquia de San Lesmes de Burgos, que recurría a un "bufete [léase mesa] de nogal (...) con Barrotes de Yerro y tres Navetas con sus Zerraduras y una llave (...)", dado que "en ellas se encontró (...) Dinero en oro y plata"141.

\section{Tabla 4}

\section{Muebles contenedores para guardar dinero y extracción estamental}

\begin{tabular}{|l|c|c|c|c|c|c|c|c|c|}
\hline & \multicolumn{8}{|c|}{ Muebles contenedores para ocultar monedas } \\
\hline Estamento & Arca & $\%$ & Arcón & $\%$ & Escritorio & $\%$ & Papelera & $\%$ \\
\hline General & 9 & 60 & 8 & 57.1 & 9 & 18.7 & 0 & 0 \\
\hline Nobiliar & 6 & 40 & 4 & 28.6 & 23 & 47.9 & 6 & 75 \\
\hline Clerical & 0 & 0 & 2 & 14.3 & 16 & 33.4 & 2 & 25 \\
\hline BURGOS & 15 & 100 & 14 & 100 & 48 & 100 & 8 & 100 \\
\hline
\end{tabular}

56 Fuente: AHPB. Protocolos Notariales. Múltiples Legajos.

Visto con mayor detalle, y de una manera más pormenorizada -véase Tabla 4-, se pueden afirmar que el arca y el arcón eran los muebles contenedores a que recurrían los integrantes del estamento general, los "pecheros", mientras que los nobles y los clérigos se decantaban abiertamente, sobre todo, por los escritorios y las papeleras. El arca era al 60\% la "caja de caudales" del estamento llano. El otro $40 \%$ fue la opción de la nobleza rentista. A los eclesiásticos no se les pueden atribuir, en ningún caso, tal estrategia. Los arcones están igualmente asociados a los "pecheros (57.1\%), y, en menor grado, a los nobles (28.6\%) y a los clérigos (14.3\%). El escritorio fue la opción preferente de los nobles (47.9\%) y en menor medida de los eclesiásticos (33.4\%), aunque, y con mucho, eran los muebles a que recurrían con fruición (66.7\%). El escritorio era para los paupérrimos del estamento general una opción minoritaria (18.7\%). La papelera estaba, al parecer, descartada para los "pecheros", y era el mueble preferido por nobles $(75 \%)$ y clérigos $(25 \%)$ para resolver la problemática de proteger sus dineros en efectivo de las miradas ajenas.

138 AHPB. PN. Ángel Arnaiz. Legajo 7177 (4 de octubre de 1784), folio 183.

139 AHPB. PN. Miguel Varona. Legajo 7207 (16 de enero de 1768), folio 239.

140 Dado que la inmensa mayoría de los clérigos preferían el escritorio como "caja fuerte".

141 Archivo Municipal de Burgos. HI-4967 (3 de enero de 1750), sin foliar. 


\section{Estancias, muebles y dinero en efectivo}

Para el tratamiento de en qué estancias se encontraban emplazados los muebles contenedores destinados a salvaguardar los dineros en efectivo de los burgaleses del Setecientos hemos de partir, de nuevo, de una lógica cuantitativa esencial. Los escribanos sólo hicieron compatible el tratamiento de los caudales atesorados, los muebles en los que yacían y las estancias en que se hallaban encuadrados tales muebles, de manera simultánea, en el 42.3\% (52 documentos). Los inventarios de bienes en que se describe el dinero y el mueble suponen 123 hallazgos. Eso significa, también, que nos movemos en un terreno resbaladizo, dado que sólo llegamos al $11.4 \%$ de los documentos en los que tenemos constancia de la existencia de dinero en efectivo (455 documentos). Sin olvidar, por supuesto, en ningún momento tales circunstancias, los resultados devenidos del tratamiento de lo accesible nos proporcionan una visión estereoscópica que considero creíble y aún sostenible, a pesar de las dramáticas carencias de información reconocibles. No llegamos a todas las categorías socio-profesionales con la misma intensidad. Por encima del $70 \%$ son más acertados los análisis que se proyectan sobre comerciantes (75\%), tenderos y empleados de Hacienda (con el $71.4 \%$, respectivamente) ${ }^{142}$. Más matizadas han de ser las apreciaciones sobre nobles rentistas $(66.7 \%)$, clérigos (44.4\%) y artesanos (43.7\%). Tendrán una carga de inexactitud importante los comentarios sobre los escribanos (33.3\%), los empleados de las administraciones eclesiásticas (22.2\%) y los profesionales de los servicios públicos (20\%). No disponemos de ningún inventario de hilanderas y labradores, y mucho menos de jornaleros, en este aserto de saber en qué muebles y en qué estancias guardaban el dinero en efectivo los burgaleses del Setecientos.

Esta problemática se aborda desde dos puntos de vista, que, a la postre, son dialécticamente compatibles, en la práctica. En primera instancia, en qué estancias tenían ubicados los muebles contenedores de dinero cada una de las categorías socio-profesionales y, en segundo término, cuáles eran los muebles más idóneos en las distintas estancias de los interiores domésticos. Por lo que respecta a la primera cuestión, la perspectiva global es, en sí misma, muy clarificadora. El 57.7\% de los muebles implicados residían en el "Quarto Pral", aunque con importantes matizaciones si descendemos al pormenor de las categorías socio-profesionales. El $71.4 \%$ de dichos muebles en manos de artesanos se ubicaba en esa estancia, en especial arcones. El 83\% en las casas de los clérigos, con rotunda predilección por los escritorios y en menor medida los arcones. El 100\% de estos muebles -escritorios, papeleras y arcones- reposaban para procuradores, profesionales de los servicios públicos y militares en el cuarto principal. Los empleados de Hacienda se decantaban al 40\% por esas estancias preferían los despachos, estrados y oratorios-, y algo similar les ocurría a los profesionales de las administraciones eclesiásticas y a los nobles rentistas ( $50 \%$ de

142 Los militares el $100 \%$. 
tales muebles en la habitación principal). Los tenderos (40\%) y los comerciantes (33.3\%) -con escritorios y arcones- desviaban sus costumbres protectoras desde la intimidad del cuarto dormitorio hasta el refugio del dinero en los mostradores, escritorios, arcas y papeleras de sus tiendas y trastiendas -donde se ubicaban, respectivamente, el 40 y el $55.6 \%$ de tales muebles-. El efecto mercader postula la salvaguarda del dinero hacia las estancias comerciales al 17.3\%. Es mayoritaria, como se ha dicho, entre los comerciantes al por mayor, algo más tenue entre los tenderos, comerciantes al por menor, y más reducida en los artesanos (14.3\%) y un empleado de Hacienda (20\%). Las estancias de segundo orden absorben el 9.6\%. Se han destacado con independencia de ellas el "Quarto del Jardín" (1.9\%), el "Quarto del despacho" o "Gabinete" -con el 5.8\%, respectivamente- y las habitaciones del entresuelo y portal (1.9\%). Sumadas estas cuatro últimas ascienden hasta el $22 \%$, lo que las colocaría en segundo lugar de las preferencias de protección del dinero, entre el cuarto principal (57.7\%) y la tienda o trastienda (17.3\%).

La segunda perspectiva -véase Tabla 5- sustancia, en resumidas cuentas, lo anterior, al fijar la atención en qué mueble contenedor de dinero era el más 58 habitual en cada estancia. En el "Quartto Pral" era el escritorio (43.4\%), seguido del arcón (23.4\%), la mesa y la papelera (10\%, respectivamente), el archivo (6.6\%) y, a la postre, el arca y el cajón (con el 3.3\% en cada caso). En las estancias de segundo orden, prima el arca (40\%) y el arcón, el escritorio y la mesa quedan relegados al $20 \%$, respectivamente. En la tienda, el mostrador es la opción más utilizada (22.3\%) y se produce una atomización estadística importante, pues aparecen el arcón, el arca, el escritorio, la papelera, el cajón, el armario y el baúl con el $11.1 \%$ en cada caso. En el "Quarto del Jardín" y en los entresuelos y el portal prima el escritorio al $100 \%$. En los despachos y gabinetes impera la papelera en igual porcentaje, mientras que en el "Quarto del Estrado" o en el "Quarto Oratorio"143 se encontraban instalados escritorios, papeleras y cajones a partes iguales.

143 Sanz de la Higuera (2017b: 3-27). 
Tabla 5

Estancias, muebles y dinero en efectivo (Burgos, siglo XVIII)

\begin{tabular}{|c|c|c|c|c|c|c|c|c|c|c|}
\hline \multirow[b]{2}{*}{ Muebles } & \multicolumn{10}{|c|}{ ESTANCIAS, MUEBLES CONTENEDORES Y DINERO EN EFECTIVO } \\
\hline & $\begin{array}{l}\text { Quarto } \\
\text { principal }\end{array}$ & $\%$ & $\begin{array}{c}\text { Quartos } \\
\text { secundarios }\end{array}$ & $\%$ & Tienda & $\%$ & $\begin{array}{l}\text { Quarto } \\
\text { del jardín }\end{array}$ & $\%$ & $\begin{array}{l}\text { Quarto } \\
\text { despacho }\end{array}$ & $\%$ \\
\hline Arcón & 7 & 23.4 & 1 & 20 & 1 & 11.1 & & & & \\
\hline Arca & 1 & 3.3 & 2 & 40 & 1 & 11.1 & & & & \\
\hline Escritorio & 13 & 43.4 & 1 & 20 & 1 & 11.1 & 1 & 100 & & \\
\hline Mesa & 3 & 10 & 1 & 20 & & & & & & \\
\hline Archivo & 2 & 6.6 & & & & & & & & \\
\hline Papelera & 3 & 10 & & & 1 & 11.1 & & & 2 & 66.7 \\
\hline Cajón & 1 & 3.3 & & & 1 & 11.1 & & & & \\
\hline Total & 30 & 100 & 5 & 100 & & & 1 & 100 & & \\
\hline Armario & & & & & 1 & 11.1 & & & & \\
\hline Mostrador & & & & & 2 & 22.3 & & & & \\
\hline Baúl & & & & & 1 & 11.1 & & & & \\
\hline Total & & & & & 9 & 100 & & & & \\
\hline Contador & & & & & & & & & 1 & 33.3 \\
\hline \multirow[t]{2}{*}{ Total } & & & & & & & & & 3 & 100 \\
\hline & $\begin{array}{l}\text { Quarto del } \\
\text { estrado y } \\
\text { oratorio }\end{array}$ & $\%$ & $\begin{array}{c}\text { Entresuelo } \\
\text { y portal }\end{array}$ & $\%$ & & & & & & \\
\hline \multicolumn{11}{|l|}{ Arcón } \\
\hline Arca & 1 & 33,3 & 1 & 100 & & & & & & \\
\hline \multicolumn{11}{|l|}{ Escritorio } \\
\hline \multicolumn{11}{|l|}{ Mesa } \\
\hline Archivo & 1 & 33,3 & & & & & & & & \\
\hline \multicolumn{11}{|l|}{ Papelera } \\
\hline Cajón & 1 & 33,3 & & & & & & & & \\
\hline Total & 3 & 100 & 1 & 100 & & & & & & \\
\hline \multicolumn{11}{|l|}{ Armario } \\
\hline \multicolumn{11}{|l|}{ Mostrador } \\
\hline \multicolumn{11}{|l|}{ Baúl } \\
\hline \multicolumn{11}{|l|}{ Total } \\
\hline \multicolumn{11}{|l|}{ Contador } \\
\hline Total & & & & & & & & & & \\
\hline
\end{tabular}

Fuente: AHPB. Protocolos Notariales. Múltiples Legajos.

\section{El dinero "prefería" el nogal}

Las estrategias urdidas en los hogares burgaleses del siglo XVIII para proteger sus caudales implicaban la elección, más o menos consciente y deliberada, de unos muebles contenedores para dicha misión, con la consiguiente discriminación de otros, probablemente considerados menos seguros. Ese mobiliario protector -véase Tabla 6- 
144 estaba fabricado, sobre todo, en nogal -el $77.3 \%$ de los 123 muebles descritos presentan esa "hechura"-. En segundo término, el pino (20.3\%) y a mucha distancia, el roble ${ }^{145}$, el castaño ${ }^{146}$ y el palo santo ${ }^{147}$-con un $0.8 \%$, respectivamente-

El contraste del peso relativo de las maderas de dichos muebles entre sí nos depara algunas peculiaridades significativas. Con cierto desparpajo, me atrevo a diferenciar cuatro situaciones esenciales en el uso de la madera de los muebles para guardar el dinero. En primera instancia, los hogares con usufructo de mucho pino y poco nogal. Eso ocurría, básicamente, en las casas de las hilanderas, dado su recurso a las arcas como mueble contenedor del dinero. En segundo término, aquellos hogares en que únicamente se utilizaba el nogal. Se trata de labradores, comerciantes y militares. En tercer lugar, aquellas viviendas en las que se privilegiaba el nogal, mucho nogal, y se discriminaba el pino. Ello sucedía en la mayoría de las demás categorías socioprofesionales. Es significativa la situación entre los artesanos (87.5\% de nogal) con arcas, arcones y escritorios elaborados en nogal. Los tenderos se decantaban ligeramente por el nogal (57.1\%), dejando al pino (28.6\%) y al roble (14.3\%) a bastante distancia. Los escribanos degustaban más nogal $(66.7 \%)$ que pino $(22.2 \%)$ o castaño (11.1\%), básicamente en escritorios y algún que otro cofre (pino), arca (castaño) y papelera (pino). Los procuradores del número se acogían al nogal (88.9\%) -en 60 escritorios y archivos- y dejaban el pino para las papeleras. Los empleados de Hacienda recurrían al nogal de forma preferente (71.4\%) -escritorios, contadores y cajones- y escasamente al pino -papeleras y contadores-. Los profesionales de las administraciones eclesiásticas (88.9 \% del nogal) se optaban, sobre todo, por los escritorios y aparece, de manera tímida, alguna papelera. Los profesionales de los servicios públicos se acogían esencialmente al nogal (80\%) -en especial en los escritorios y algunas, pocas, arcas, arcones y papeleras- mientras que el pino (20\%) se circunscribía a arcas y baúles de escasa calidad. A la postre, los clérigos eran, también, filo-nogaleños (81.5\%) -la casi totalidad de sus escritorios estaba fabricada con dicha madera-. Su recurso al pino (14.8\%) era anecdótico -algún que otro cajón, baúl y cofre, de escasa entidad-. El escritorio de palo santo y marfil del canónigo del Cabildo catedral José Barrio Mirón era una "rara avis" en el panorama mobiliario burgalés del XVIII. Este eclesiástico gozaba de una auténtica joya, una "caja de caudales" extemporánea e irrepetible. En última instancia, los nobles rentistas preferían papeleras y baúles de pino y arcones y mesas de nogal al $50 \%$.

144 El análisis está supeditado, obviamente, a la documentación recopilada, razón que explica que hemos de mantener ciertas cautelas a la hora de considerar indubitables las conclusiones que pergeñamos. El margen de error es notorio: únicamente accedemos al $27 \%$ de los hogares con dinero en efectivo.

145 Véase el arcón de la tendera Ángela Dueñas. AHPB. PN. Juan Antonio Fernández Guilarte. Legajo 6993 (5 de agosto de 1723), folio 314.

146 Véase el arca del escribano Juan Antonio Herrera Tomé. AHPB. PN. Gregorio Padrones. Legajo 7138 (29 de septiembre de 1779), folio 673.

147 Véase el escritorio del clérigo José Barrio Mirón. AHPB. PN. Juan Antonio Fernández Guilarte. Legajo 6988 (12 de mayo de 1718), folio 241. 
El hecho de que la inmensa mayoría de los muebles contenedores tuviera hechura de madera hace resaltar, sin embargo, con luz propia, la existencia, casi anecdótica pero sugestiva, de cofres y cajas de acero como las aparecidas en los inventarios del tendero y tabernero Domingo Benito -"Un cofrezitto de Azero Colado sin llave"-148 o "Una Caja de Azero"149 O, a la postre, del mayordomo del Cabildo Catedral Gabriel Díaz Salvador -"Un Cofre de Yerro"150.

\section{Tabla 6}

\section{Maderas, muebles y metales de monedas (Burgos, siglo XVIII)}

\begin{tabular}{|c|c|c|c|c|c|c|c|c|c|c|c|c|c|}
\hline \multirow{2}{*}{ Hogares } & \multirow[b]{2}{*}{ Profesiones } & \multicolumn{4}{|c|}{ Pino } & \multicolumn{4}{|c|}{ Nogal } & \multicolumn{4}{|c|}{ Castaño } \\
\hline & & Muebles & Oro\% & Plata\% & Vellón\% & Muebles & Oro\% & Plata\% & Vellón\% & Muebles & Oro\% & Plata\% & \%Vellón\% \\
\hline \multirow[t]{2}{*}{6} & Hilanderas & 5 & 39.9 & 38.4 & 21.7 & 1 & 61.5 & 38.5 & 0 & & & & \\
\hline & $\%$ & 83.3 & & & & 16.7 & & & & & & & \\
\hline \multirow[t]{2}{*}{3} & Labradores & 0 & & & & 3 & 20.5 & 12.8 & 66.7 & & & & \\
\hline & $\%$ & & & & & 100 & & & & & & & \\
\hline \multirow[t]{2}{*}{14} & M/Artesanos & 2 & 50 & 50 & 0 & 12 & 55.9 & 30.6 & 13.5 & & & & \\
\hline & $\%$ & 14.3 & & & & 85.7 & & & & & & & \\
\hline \multirow[t]{2}{*}{9} & Comerciantes & 0 & & & & 9 & 40.4 & 33.2 & 26.4 & & & & \\
\hline & $\%$ & & & & & 100 & & & & & & & \\
\hline \multirow[t]{2}{*}{5} & Tenderos & 2 & 72.2 & 27.7 & 0.1 & 3 & 25.7 & 66 & 8.3 & & & & \\
\hline & $\%$ & 40 & & & & 60 & & & & & & & \\
\hline \multirow[t]{2}{*}{6} & Escribanos & 0 & & & & 5 & 41.2 & 38.5 & 20.3 & 1 & 95.5 & 0 & 4.5 \\
\hline & $\%$ & & & & & 100 & & & & & & & \\
\hline \multirow[t]{2}{*}{6} & Procuradores & 1 & 80.9 & 19.1 & 0 & 5 & 64.2 & 26.1 & 9.7 & & & & \\
\hline & $\%$ & 16.7 & & & & 83.3 & & & & & & & \\
\hline \multirow[t]{2}{*}{4} & Admón. Hacienda & 0 & & & & 4 & 55.4 & 41.2 & 3.4 & & & & \\
\hline & $\%$ & & & & & 100 & & & & & & & \\
\hline \multirow[t]{2}{*}{8} & $\begin{array}{l}\text { Admón. } \\
\text { Eclesiástica }\end{array}$ & 1 & 86.1 & 13.9 & 0 & 7 & 69.4 & 25.8 & 4.8 & & & & \\
\hline & $\%$ & 12.5 & & & & 87.5 & & & & & & & \\
\hline \multirow[t]{2}{*}{4} & Servicios públicos & 1 & 61.5 & 38.5 & 0 & 3 & 70.3 & 29.7 & 0 & & & & \\
\hline & $\%$ & 12.5 & & & & 75 & & & & & & & \\
\hline \multirow[t]{2}{*}{5} & Nobleza rentista & 3 & 85.9 & 13.7 & 0.4 & 2 & 45.6 & 50.3 & 4.1 & & & & \\
\hline & $\%$ & 60 & & & & 40 & & & & & & & \\
\hline \multirow[t]{2}{*}{13} & Clérigos & 1 & 76.6 & 23.4 & 0 & 12 & 57.9 & 24.7 & 17.4 & & & & \\
\hline & $\%$ & 7.7 & & & & 92.3 & & & & & & & \\
\hline \multirow[t]{2}{*}{84} & BURGOS & 16 & 62.9 & 30.2 & 6.9 & 67 & 52.7 & 31.9 & 15.4 & 1 & 95.5 & 0 & 4.5 \\
\hline & $\%$ & 19 & & & & 79.8 & & & & 1.2 & & & \\
\hline
\end{tabular}

Fuente: AHPB. Protocolos Notariales. Múltiples Legajos.

148 Tasado en 12 reales. AHPB. PB. Lázaro Santamaría. Legajo 6871 (7 de octubre de 1716), folio 53.

149 Tasada en 8 reales. AHPB. PN. Juan Antonio Fernández Guilarte. Legajo 7001 (27 de septiembre de 1731), folio 648.

150 Tasado en 150 reales. AHPB. PN. José Fernández Guilarte. Legajo 6899 (6 de agosto de 1708), folio 300. 
En última instancia, como colofón a estos asertos, una aproximación a la relación entre los metales de las monedas y las maderas de los muebles contenedores -Tabla 6-. Esta dialéctica no impugna lo aseverado anteriormente, es más lo apuntala con nitidez. En primer lugar, queda consolidada la tendencia de una mayor preferencia por los muebles de nogal, al $79.8 \%$, muy por encima del pino, $19 \%$, y, por supuesto, del castaño (1.2\%). En segundo término, la indubitable demostración de que la ley de Gresham se cumplía, aún en su inconsciente desconocimiento, en los hogares burgaleses del XVIII, aunque más en lo tocante a los muebles de pino y castaño que los de nogal. La estrategia de los castellanos era retirar de la circulación, y reforzar su afán de preservar, las monedas de oro en recipientes de pino -esencialmente arcas y arcones- en la siguiente fórmula: el oro suponía el $62.9 \%$ de las piezas atesoradas, frente al $30.2 \%$ de la plata y el $6.9 \%$ de la muy escasa calderilla de vellón, apenas ocultado. El vellón se usaba para los pagos habituales y se preservaba el oro y la plata. Como era de esperar, entre las hilanderas y pobres de solemnidad la "alquimia" monetaria estaba ligeramente inclinada al oro (39.9\%) pero con un notable componente argentífero (38.4\%) y un categórico vellón (21.7\%), y ello en recipientes mayoritariamente de pino (83.3\%) frente al nogal $(16.7 \%)$-donde si primaba más el oro (61.5\%) que la plata (38.5\%), sin nada de vellón-. En los hogares artesanos se producía una notoria igualación entre oro y 62 plata, preservado el dinero en efectivo en muebles de pino. Las demás categorías socio-profesionales para las que disponemos simultáneamente de información sostenible sobre mueble, madera y monedas el sesgo se basculaba hacia el oro en índices muy elevados, con muy escaso vellón. Es sintomático lo ocurrido en las mansiones nobles, dadas más al pino (60\%) que al nogal (40\%). En los muebles de pino se guardaba más oro (85.9\%) que plata (13.7\%) o vellón (0.4\%). En nogal se ocultaba ligeramente más plata (50.3\%) que oro $(45.6 \%)$ o vellón (4.1\%). La pauta de análisis nos lleva a la conclusión de que a más cantidad de dinero en efectivo, y más si éste era de "buena moneda", la necesidad de protección era más imprescindible y perentoria, en especial en las categorías socio-profesionales de mayor alcurnia y con más temor ante una posible depredación externa.

Cuando el mueble era de nogal -básicamente escritorios- la relación era algo más equilibrada -véase Tabla 6-. El oro suponía el $52.7 \%$ de las monedas, la plata el $31.9 \%$ y el vellón el $15.4 \%$. En los muebles de castaño, el oro $(95.5 \%)$ era absolutamente sobresaliente -el vellón al 4.5\%-, aunque se producían situaciones sintomáticas. Los labradores y hortelanos usaban, en exclusiva, nogal -arcas, escritorios y mesas-, con un manifiesto atesoramiento de vellón (6.7\%) frente a oro (20.5\%) o plata (12.8\%). La tendencia general era disponer, en reserva, de más oro, pero sin la "exageración" de los muebles de pino, si bien tenderos (al 66\%) o nobles (al 50.3\%) disponían de más plata que de oro. En la generalidad de las categorías socio-profesionales con dinero oculto en muebles de nogal, obviadas las citadas excepciones, lo habitual era algo más de oro en primer lugar, un porcentaje cercano de plata en segundo término y una presencia de vellón significativa, aunque nunca mayoritaria. Digno de mención es, a mi entender, el 26.4\% de monedas de vellón 
en las tiendas de mercaderes al por mayor, de paños y sedas ${ }^{151}$, el $20.3 \%$ de los escribanos y el $17.4 \%$ de los clérigos.

\section{A modo de conclusión...}

El afán por preservar el dinero en efectivo antes del recurso a los depósitos en las entidades bancarias y financieras nos catapulta a los interiores domésticos de las casas y las mansiones del Burgos del Setecientos. Aunque siempre desde la más estricta y cautelosa honradez científica sobre los márgenes de credibilidad y autenticación de la información obtenida en la documentación de archivo, se puede afirmar, sin temor a excesivos yerros, que el burgalés del XVIII recurría a algunos de los muebles contenedores que tenía en casa para ocultar sus caudales de aviesas miradas. En el Setecientos, la mejora económica de gran parte de la población, y el incremento, creciente, de sus reservas monetarias, inducía a generar estrategias de protección del dinero en el interior de muebles, provistos de "Secreto", en los que confiar ciegamente. Los "pecheros" abocados a arcas y arcones -en su inmensa mayoría de pino- y los privilegiados a escritorios y papeleras -con el nogal como madera de "hechura"-. El dinero en efectivo era ocultado sobre todo en las estancias más íntimas -el "Quartto Pral"-, con la deriva de mostradores, papeleras, escritorios y arcas en las tiendas y trastiendas de los comerciantes de paños y tenderos. Más minoritario, pero también efectivo, era su ocultación en despachos, gabinetes, estrados y oratorios. Se trata, en suma, de atesorar, en la oscuridad de lo más íntimo, el oro y la plata de las monedas acumuladas para usufructuar el vellón como método de pago, con el imprescindible concurso de balanzas para pesar moneda habidas en múltiples casas de la ciudad ${ }^{152}$. Gran parte de ese dinero en efectivo constituía un "colchón" esencial para el abono de los desembolsos inevitables tras el óbito del titular del inventario post-mortem. Los 900 reales que quedaron a la muerte del jornalero Manuel Páramo se liquidaron en el pago "[d]el funeral y entierro que se le hizo, renta de casa y otras deudas"153. El maestro de jalmería José Calvo dejó 1.000 reales "... al tiempo que murió, Con los quales ha Ido pagando y Satisfaziendo el entierro, misas y demás Sufragios que se han dho por su alma y otras Cosas"154.

\footnotetext{
151 El recurso al mostrador y al cajón de la mesa de la tienda era una circunstancia indisolublemente ligada a las estrategias de los mercaderes al por mayor. Véase Álvarez Santaló y García-Baquero (2008: 282).

152 Sanz de la Higuera (2015: 239-283).

153 AHPB. PN. Jacinto Río. Legajo 7056/2 (20 de agosto de 1764), folio 74.

154 AHPB. PN. Martín Robredo. Legajo 6969 (3 de febrero de 1729), folio 160.
} 


\section{Referencias}

Aguado de los Reyes, J. (1994). Riqueza y sociedad en la Sevilla del siglo XVII. Universidad de Sevilla.

Aguiló-Alonso, M.P. (2011). Arquetas alemanas de hierro, joyeros o cajas fuerte. Estudio del Mueble, (13), 10-13.

Alloza Aparicio, A. (2000). Ladrones, rateros y estafadores. En, La vara quebrada de la justicia. Un estudio histórico sobre la delincuencia madrileña entre los siglos XVI y XVIII (pp. 143-185). Los Libros de la Catarata.

Álvarez Santaló, L.C. y García-Baquero González, A. (1980a). La nobleza titulada en Sevilla, 1700-1834 (aportación al estudio de sus niveles de vida y fortuna). Historia, Instituciones, Documentos, (7), 18-19.

Álvarez Santaló, L.C. y García-Baquero González, A. (1980b). Funcionalidad del capital andaluz en vísperas de la primera industrialización. Revista de Estudios Regionales, (5), 101-134.

Álvarez Santaló, L.C. y García-Baquero, A. (1998). Riqueza y pobreza del clero secular en la Sevilla del Antiguo Régimen (1700-1834). Trocadero, (8-9), 20-21.

64 Álvarez Santaló, L.C. y García-Baquero González, A. (2008). Modernitas. Estudios en homenaje al Profesor Baudelio Barreiro Mallón, M.R. García Hurtado (Ed.). Universidad de La Coruña.

Barrio Gozalo, M. (2000). Los obispos de Castilla y León durante el Antiguo Régimen. Junta de Castilla y León.

Blanco Anta, F. (2016). Las cajas de ahorros en España. Antecedentes históricos, legislación y proceso de reestructuración. Universidad de La Coruña.

Cano Borrego, P.D. (2014). Una aproximación al estudio de los proyectos de creación de un banco nacional en España durante la Edad Moderna. Pecvnia, (19), 157-179. http://dx.doi.org/10.18002/pec.v0i19.3586

Echalecu, J.M. (1957). El mueble español en el siglo XVIII. Anales Españoles de Arte, (30), 29-54.

Fernández Paradas, A.R. (2013). Bibliografía de la historia del mueble español (1872-2012). ASRI, Arte y Sociedad, Revista de Investigación, (3), 1-45.

Fernández Paradas, A.R. (2016). Historia de la historia del mueble en España. Teoría, historiografía y corrientes metodológicas (1872-2011). Universidad de Málaga.

Junquera Mato, J.J. (1990). Mobiliario en los siglos XVIII y XIX. En S. Rodríguez Bernís e I. Gisbert Marco (Eds.), Mueble español: estrado y dormitorio. Comunidad de Madrid.

Martínez Alcázar, E. (2008). El mueble en la vivienda murciana a finales del siglo XVIII: una visión a través de la documentación notarial. Imafronte, (19-20), 219-232. 
Maruri Villanueva, R. (1990). La burguesía mercantil santanderina, 1700-1850 (Cambio social y de mentalidad). Universidad de Cantabria.

Moreno Claverías, B. (2003). Pautas de consumo y diferenciación social en El Penedés a fines del siglo XVII. Una propuesta metodológica a partir de inventarios sin valoraciones monetarias. En J. Llopis y B. Yun (Eds.), El consumo en la España pre-industrial. Revista de Historia Económica, ( ${ }^{\circ}$ extraordinario), 207-245.

Muñoz Serrulla, M.T. (2007). Moneda y circulación monetaria: estudio a través de las operaciones del Monte de Piedad de Madrid en el siglo XVIII. Gaceta Numismática, (164), 45-66.

Noriega, J. (2015 septiembre 16). Las “cajas de yerro" que guardaban el Imperio. Espejo de navegantes: Blog de arqueología naval. https://abcblogs.abc.es/ espejo-de-navegantes/otros-temas/las-cajas-de-yerro-que-guardaban-elimperio.html

Ortego Gil, P. (2010). Hurtar a los de casa: notas sobre hurtos domésticos. Cuadernos de Historia del Derecho, (No extraordinario), 449-470.

Piera Miquel, M. (2012). Los muebles con secreto: esconder, exhibir, aprender. Revista de Historia Moderna, (30), 159-175.

Piera, M., Shelly, A. y Marsal, J. (Eds.) (2008). El mueble del siglo XVIII: nuevas aportaciones a su estudio. Ayuntamiento de Barcelona.

Pounds, N.J.G. (1999). La vida cotidiana. Historia de la cultura material. Crítica.

Sánchez-Arcilla Bernal, J. (2001). Robo y hurto en la Ciudad de México a fines del siglo XVIII. Cuadernos de Historia del Derecho, (8), 43-109.

Sanz de la Higuera, F. (2006). Seminario de San Nicolás (Burgos, 1743): una rectoría apetecible, un litigio aborrecible. Boletín de la Institución Fernán González (BIFG), (232), 149-178.

Sanz de la Higuera, F. (2009). Pajas, catres, cujas, camas, ... El lecho cotidiano en el Antiguo Régimen: Burgos (1740-1780). Cuadernos de Investigación Histórica (CIH), (26), 435-499.

Sanz de la Higuera, F. (2010). La medida del tiempo en Burgos: Relojes a mediados del siglo XVIII. Historia Social, (67), 23-49.

Sanz de la Higuera, F. (2011). Evolución de los lechos cotidianos y los menajes nocturnos en el XVIII burgalés. $\mathrm{CIH}$, (28), 389-431.

Sanz de la Higuera, F. (2012). Luz y color a raudales. Vidrieras en los interiores domésticos: Burgos en el Setecientos. ASRI, Arte y Sociedad, Revista de Investigación, (2), 1-33.

Sanz de la Higuera, F. (2013a). Buena moneda y mala moneda en los hogares de Burgos en el siglo XVIII. Pecvnia, (16/17), 13-40. http://dx.doi.org/10.18002/ pec.v0i16/17.1333

Sanz de la Higuera, F. (2013b). Aproximación al devenir del canapé en los interiores domésticos burgaleses del XVIII. Cuadernos de Historia Moderna, (38), 139-161. 
Sanz de la Higuera, F. (2013c). La iluminación doméstica en el Burgos del siglo XVIII. ASRI, Arte y Sociedad, Revista de Investigación, (5), 1-36.

Sanz de la Higuera, F. (2013d). Aproximación a la mesa de los burgaleses. Cuberterías y platos en el Setecientos. En M. García Fernández (Coord.). Cultura material y vida cotidiana moderna: Escenarios. Sílex.

Sanz de la Higuera, F. (2013e). Relojes, espacios y tiempo. Burgos en el Setecientos. Historia Social, (77), 23-47.

Sanz de la Higuera, F. (2013f). A la moda ilustrada o a la vieja usanza nobiliar. Viviendas del clero capitular burgalés en el siglo XVIII. Historia y Genealogía, (3), 219-242.

Sanz de la Higuera, F. (2014a). Una herencia problemática en el Burgos del Setecientos. El reparto de los bienes de Alonso de Vivar (1781). BIFG, (249), 437-461.

Sanz de la Higuera, F. (2014b). Arcas, arcones, cofres, baúles y armarios. El mobiliario contenedor en el XVIII burgalés. En M. Gomero Rojas y F. Núñez Roldán (Coords.), Entre lo real y lo imaginario. Estudios de historia moderna en homenaje al prof. León Carlos Álvarez Santaló. Universidad de Sevilla, 461-478.

66 Sanz de la Higuera, F. (2014c). A la mesa de los burgaleses del Setecientos: mantelerías, cuberterías, vidrios y vidriados. Investigaciones Históricas, (34), 107-130.

Sanz de la Higuera, F. (2015a). Vellón, oro y plata, cultura material y "balanzas para pesar moneda" en el XVIII burgalés. CIH, (32), 239-283.

Sanz de la Higuera, F. (2015b). La cultura material de los tesoreros generales de la Santa Cruzada en el Burgos del siglo XVIII. Cuadernos de Estudios del Siglo 18, (25), 320-321.

Sanz de la Higuera, F. (2016). Cultura material, dinero en efectivo y recuperación económica en el Burgos del XVIII. CIH, (33), 85-121.

Sanz de la Higuera, F. (2017a). Perspectivas de negocio y cultura material en una saga de comerciantes burgaleses del XVIII. Los Bernáldez de Velasco. BIFG, (255), 361-384.

Sanz de la Higuera, F. (2017b). Oratorios en los interiores domésticos en el Burgos del Setecientos. ASRI, Arte y Sociedad, Revista de Investigación, (12), 1-36.

Sanz de la Higuera, F. (2018a). Niveles de renta y cultura material de los profesionales de la construcción en el Burgos del XVIII. Tiempos Modernos (37).

Sanz de la Higuera, F. (2019). La cultura material entre los maestros tajadores de carne en el Burgos del Setecientos. Crónica Nova (45), 377-410.

Sobrado Correa, H. (2003). Los inventarios post-mortem como fuente privilegiada para el estudio de la historia de la cultura material en la Edad Moderna. Hispania, (215), 825-862. 